\title{
Navigating the treatment landscape in multiple myeloma: which combinations to use and when?
}

\author{
Hartmut Goldschmidt ${ }^{1} \cdot$ John Ashcroft ${ }^{2} \cdot$ Zsolt Szabo $^{3} \cdot$ Laurent Garderet $^{4,5}$ \\ Received: 23 November 2017 / Accepted: 6 November 2018 / Published online: 23 November 2018 \\ (C) The Author(s) 2018
}

\begin{abstract}
Multiple myeloma is one of the most common hematological malignancies, affecting mainly elderly patients. The treatment landscape for the management of this disease has evolved significantly over the past 15 years, and a vast array of therapeutics is now available, including immunomodulatory drugs, proteasome inhibitors, histone deacetylase inhibitors, and monoclonal antibodies. As a result, deciding which drugs to use and when, and whether these should be used in a particular order or combination, can be challenging. Although combination regimens are often associated with deeper responses and better longterm outcomes than monotherapy, and are becoming the standard of care, they may result in significant incremental toxicity; hence, a sequential approach may be more appropriate for some patients. In particular, treatment choices can vary depending on whether the patient has newly diagnosed multiple myeloma, is eligible for transplant, has relapsed and/or refractory multiple myeloma, or is considered to have high-risk disease. In this review, we discuss factors to be taken into account when making treatment decisions in each of these settings. We also briefly discuss possible therapeutic strategies involving agents that may become available in the future.
\end{abstract}

Keywords Multiple myeloma $\cdot$ Combination therapy $\cdot$ Sequential therapy $\cdot$ Treatment regimen

\section{Introduction}

Multiple myeloma (MM) is a clonal plasma cell disorder that accounts for approximately $10 \%$ of hematological malignancies [1]. The disease has an estimated incidence of 4.5-6.0 per 100,000 people per year in Europe and primarily affects elderly patients, with a median age at diagnosis of 72 years [1]. Although MM remains an incurable disease, the development and introduction of therapies such as the immunomodulatory

Hartmut Goldschmidt

hartmut.goldschmidt@med.uni-heidelberg.de

1 Internal Medicine V and National Center for Tumor Diseases (NCT), University Clinic Heidelberg, 69120 Heidelberg, Germany

2 Department of Haematology, Mid Yorkshire Hospitals NHS Trust, Wakefield, UK

3 Clinical Development, Amgen (Europe) GmbH, Zug, Switzerland

4 INSERM, UMR S 938, Proliferation and Differentiation of Stem Cells, Paris 75012, France

5 AP-HP, Hôpital Saint Antoine, Département d'hématologie et de thérapie cellulaire, Sorbonne Université, Paris 6, Paris, France drugs thalidomide and lenalidomide and the proteasome inhibitor bortezomib have led to improved overall survival (OS) $[2,3]$. Recent years have also seen the development and approval of numerous new treatments for patients with MM, including the second-generation proteasome inhibitors carfilzomib and ixazomib, of which carfilzomib demonstrated improved survival in a head-to-head study of carfilzomib plus dexamethasone versus bortezomib plus dexamethasone [4]. Other therapies with different mechanisms of action have emerged, including the immunomodulatory agent pomalidomide, the alkylating agent bendamustine, the histone deacetylase (HDAC) inhibitor panobinostat, and the monoclonal antibodies elotuzumab and daratumumab [5, 6]. Results from clinical trials suggest that the use of these agents may help to improve outcomes further [7-16].

Given the dramatic increase in therapeutic options available for patients with MM, one of the main challenges for physicians and funding bodies is deciding which agents to use and in which order and/or combination [17, 18]. Clonal heterogeneity is often observed in patients with MM, and it has been suggested that suboptimal treatment may lead to eradication of sensitive subclones while allowing resistant clones to expand [19]. As a result, combination therapy using 
agents from different drug classes with distinct and synergistic mechanisms of action is increasingly being utilized in an attempt to remove more subclonal groups, to reduce the risk of developing drug resistance and to induce a deeper response [5, 19]. For example, preclinical and clinical data suggest that a synergistic effect is observed when immunomodulatory drugs and proteasome inhibitors or monoclonal antibodies are used in combination [7, 10, 16, 20-22]. Immunomodulatory drugs stimulate natural killer cells and proteasome inhibitors may enhance natural killer cell-mediated cytotoxicity by reducing expression of host protein fragments on major histocompatibility complex (MHC) class I molecules [20]. In addition, monoclonal antibodies induce cell death via a number of mechanisms including antibody-dependent cell-mediated cytotoxicity (ADCC) and immunomodulatory drugs may enhance this anti-myeloma activity by activating the effector cells of ADCC [22]. However, when making treatment decisions, it is important to consider patient-related factors (i.e., age, comorbidities, and eligibility for autologous stem cell transplantation (ASCT)), disease-related factors (i.e., cytogenetics, disease burden, and aggressiveness of relapse in the relapsed/refractory disease setting) and previous therapies (i.e., number of previous therapy lines, response to previous therapies, and tolerability to previous therapies) $[5,17,23]$. Physicians also need to consider the balance between increasing the depth of response from a drug regimen and exposing patients to increased toxicity [24]. Although a deeper response is associated with better long-term outcomes [11, 14, 25, 26], the intensive multidrug therapy required to achieve this goal may result in significant treatment-related toxicity. Furthermore, the primary aim of treatment may differ between the newly diagnosed and relapsed/refractory settings, and this may influence the choice of drug regimen.

In this article, we review available therapies and provide guidance on the use of various treatment options in the newly diagnosed and relapsed/refractory settings. In addition, considerations for patients who are not eligible for ASCT are discussed, as well as for those who have high-risk disease.

\section{Management of patients with newly diagnosed multiple myeloma}

\section{Transplant-eligible patients}

Treatment decisions in patients with newly diagnosed MM (NDMM) are usually made on the basis of age, performance status, and comorbidities. It is also important to take the patient's preference into account [24]. In Europe, the standard of care for first-line therapy in patients up to 65 years of age and those considered to be in good clinical condition is induction therapy followed by high-dose melphalan and ASCT [1, 17]. The goals of induction therapy are to induce a deep response prior to ASCT, and this typically involves the use of combinations of two or three drugs in fit, transplant-eligible patients (Fig. 1) [1, 17, 24].

Triplet induction regimens are expected to result in deeper responses than doublet regimens, and several studies have demonstrated the efficacy of triplet combinations including the proteasome inhibitor bortezomib (Table 1) [27-34]. In patients with NDMM, induction therapy with bortezomib, thalidomide, and dexamethasone (VTD) or with vincristine, doxorubicin, and dexamethasone (VAD) has been shown to improve response rates compared with either thalidomide and dexamethasone (TD) or bortezomib and dexamethasone (VD) $[27,28,30,31]$. A number of phase 3 trials compared the different available triplet regimens; bortezomib, doxorubicin, and dexamethasone (PAD) have demonstrated higher response rates and superior progression-free survival (PFS) and OS to VAD [32], and bortezomib, cyclophosphamide, and dexamethasone (VCD) have been shown to be noninferior to PAD [33]. In a head-to-head comparison of VTD and VCD, VTD resulted in higher response rates than VCD [34]. Thus, three-drug combinations including at least bortezomib and dexamethasone are currently the standard of care before ASCT, with VTD and VCD as preferred regimens in Europe [1]. It is important to note that triplet regimens may be associated with toxicity issues. For example, the triplet VTD is associated with higher rates of peripheral neuropathy (PN) than the doublets TD and VD [27, 35]. Subcutaneous administration of bortezomib has been shown to be effective and to reduce the incidence of PN compared with intravenous administration [36]. Furthermore, the duration of treatment should be considered: the toxicity associated with a triplet regimen may be acceptable for an induction regimen, which is administered for a relatively short period. Although it is important to take toxicity into consideration when deciding on the most appropriate treatment for an individual, efficacy should be prioritized where possible, such as when making treatment decisions for fit patients who are eligible for ASCT.

While the efficacy of modern triplet combinations including the most recently approved drugs (such as carfilzomib, ixazomib, panobinostat, daratumumab, and elotuzumab) has been demonstrated in patients with relapsed and/or refractory MM(RRMM), they have not been extensively tested for firstline therapy. Nonetheless, positive results have been obtained in phase 2 trials of carfilzomib, lenalidomide, and low-dose dexamethasone (KRd) in patients with NDMM [37-39], as well as ixazomib, lenalidomide, and low-dose dexamethasone [40], and a phase 3 trial comparing KRd with bortezomib, lenalidomide, and low-dose dexamethasone (VRd) is in progress [41]. In addition, another clinical trial is investigating the use of therapy with either the triplets cyclophosphamide, lenalidomide, and dexamethasone (CRD) or cyclophosphamide, thalidomide, and dexamethasone (CTD) or a quadruple regimen, carfilzomib, cyclophosphamide, lenalidomide, and 


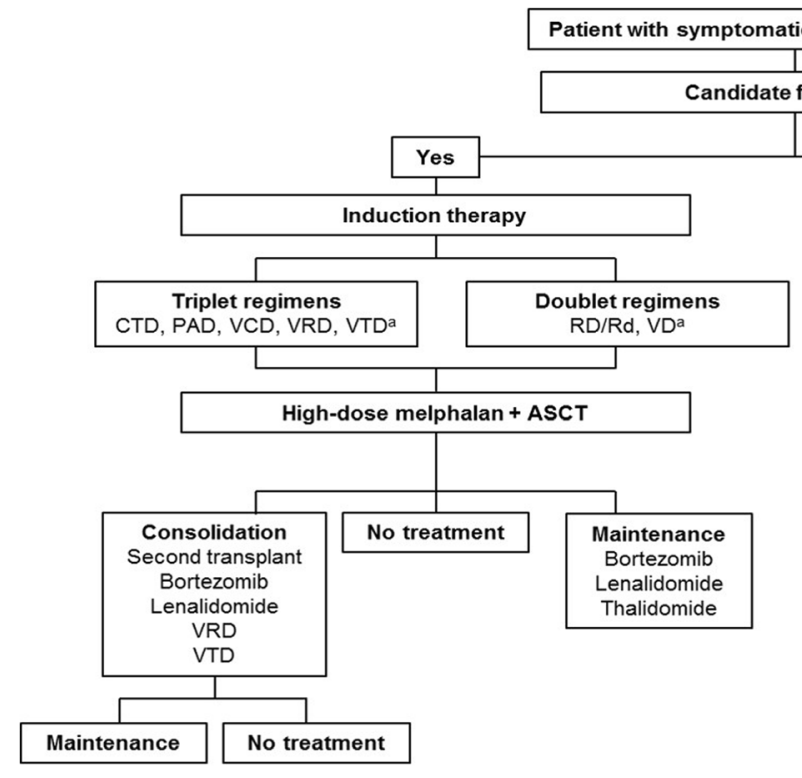

Fig. 1 Treatment algorithm for patients with newly diagnosed multiple myeloma. ASCT, autologous stem cell transplantation; $C D$, cyclophosphamide and dexamethasone; $C P R$, cyclophosphamide, prednisone, and lenalidomide; $C T D$, cyclophosphamide, thalidomide, and dexamethasone; $M M$, multiple myeloma; $M P$, melphalan and prednisone; $M P R$, melphalan, prednisone, and lenalidomide; $M P R-R$, melphalan, prednisone, and lenalidomide, with lenalidomide maintenance; $M P T$, melphalan, prednisone, and thalidomide; $P A D$, bortezomib, doxorubicin, and dexamethasone; $R d$, lenalidomide and low-dose dexamethasone; $R D$,

dexamethasone (CCRD) [42]. Findings from the randomized phase 3 Myeloma XI trial suggest that treatment with CCRD induces a deeper response than either of the triplet regimens $[43,44]$; however, it should be noted that these data are preliminary and further research is needed to investigate fully the efficacy and safety of this approach. Another ongoing study in patients with NDMM is investigating induction therapy with VRD or VRD plus the monoclonal antibody elotuzumab, followed by maintenance therapy with lenalidomide with or without additional elotuzumab [45].

Although it was previously thought that potent combination therapy should be saved for use at relapse, it is now thought that its utilization earlier may increase the chances of obtaining a deep and durable response, resulting in improved outcomes. This is based on the hypothesis that potent treatment at an early stage may increase the likelihood of eradicating the majority of, or even all, subclones [46]. In addition, patients are more likely to have disease-related complications and comorbidities at later lines of treatment, which may impact on their ability to tolerate potent drug combinations, and so the use of the most effective combination treatments before these have developed may increase the likelihood of a sustained response [46]. Although further studies will be needed to determine the benefit of modern combination treatment regimens at early therapy lines, it is expected that these will help to improve responses and long-term outcomes.

In addition to induction therapy, consolidation and maintenance therapy may be given following ASCT. Consolidation therapy typically consists of a short period of intensive treatment with the aim of improving the depth of response after transplant [17, 47]. VTD is the predominant regimen used, but studies investigating the value of consolidation are limited [17, 47-49]. In contrast, maintenance therapy typically involves use of a more prolonged course of treatment with a lower-intensity regimen, with the aim of achieving long-term disease control [17, 47]. Maintenance therapy with thalidomide, lenalidomide, or bortezomib has been shown to have some benefit [32, 50-52]. Lenalidomide has been shown to improve OS compared with placebo or no maintenance therapy; a recent meta-analysis involving 1209 patients from three phase 3 randomized clinical trials of lenalidomide maintenance after ASCT demonstrated a significantly prolonged OS compared with controls [51]. Furthermore, the Myeloma XI study of more than 2000 patients with NDMM demonstrated that maintenance with lenalidomide was associated with a significantly longer median PFS compared with observation across all patient subgroups, including in those with high-risk disease [53]. In 2017, the use of lenalidomide maintenance therapy was approved for patients with NDMM following ASCT in Europe and the USA [54, 55]. In a head-to-head trial comparing bortezomib-based induction and maintenance 
Table 1 Key phase 3 studies of doublet and triplet regimens in transplant-eligible patients with newly diagnosed multiple myeloma

\begin{tabular}{|c|c|c|c|c|c|c|c|}
\hline Study & Regimen & $N$ & ORR (\%) & $\geq \operatorname{VGPR}(\%)$ & $\mathrm{CR}(\%)$ & $\begin{array}{l}\text { Median PFS } \\
\text { (months) }\end{array}$ & $\begin{array}{l}\text { Median OS } \\
\text { (months) }\end{array}$ \\
\hline \multirow[t]{2}{*}{ Cavo [27] } & $\mathrm{TD}$ & 238 & 79 & 28 & 5 & - & - \\
\hline & VTD & 236 & 93 & 62 & 19 & - & - \\
\hline \multirow[t]{2}{*}{ Harousseau [28] } & VD & 223 & 79 & 38 & 6 & 36.0 & NR \\
\hline & VAD & 218 & 63 & 15 & 1 & 29.7 & NR \\
\hline \multirow[t]{2}{*}{ Lokhorst [29] } & TAD & 268 & - & 37 & 3 & 34.0 & 73 \\
\hline & VAD & 268 & - & 18 & 2 & 25.0 & 60 \\
\hline \multirow[t]{2}{*}{ Moreau [30] } & VD & 99 & 81 & 36 & 12 & 30.0 & - \\
\hline & VTD & 100 & 88 & 49 & 13 & 26.0 & - \\
\hline \multirow[t]{2}{*}{ Rosinol [31] } & $\mathrm{TD}$ & 127 & - & $15^{\mathrm{a}}$ & 14 & 8.2 & - \\
\hline & VTD & 130 & - & $25^{\mathrm{a}}$ & 35 & 56.2 & - \\
\hline \multirow[t]{2}{*}{ Sonneveld [32] } & VAD & 414 & - & 14 & 2 & 28 & NR \\
\hline & PAD & 413 & - & 42 & 7 & 35 & NR \\
\hline \multirow[t]{2}{*}{ Mai [33] } & VCD & 251 & - & 37.0 & 8.4 & - & - \\
\hline & PAD & 251 & - & 34.3 & 4.4 & - & - \\
\hline \multirow[t]{2}{*}{ Moreau [34] } & VCD & 169 & 83 & 56 & 9 & - & - \\
\hline & VTD & 169 & 92 & 66 & 13 & - & - \\
\hline
\end{tabular}

ORR, VGPR, and CR refer to response to induction therapy

$C R$, complete response; $N R$, not reached; $O R R$, overall response rate; $O S$, overall survival; $P A D$, bortezomib, doxorubicin, and dexamethasone; $P F S$, progression-free survival; $R d$, lenalidomide and low-dose dexamethasone; $T A D$, thalidomide, adriamycin, and dexamethasone; $T D$, thalidomide and dexamethasone; $V A D$, vincristine, doxorubicin, and dexamethasone; $V C D$, bortezomib, cyclophosphamide, and dexamethasone; $V D$, bortezomib and dexamethasone; $V G P R$, very good partial response; $V R d$, bortezomib, lenalidomide, and low-dose dexamethasone; VTD, bortezomib, thalidomide, and dexamethasone

${ }^{\text {a }}$ Proportion of patients with VGPR therapies (PAD induction, bortezomib maintenance) versus VAD induction and thalidomide maintenance, the bortezomib group achieved superior PFS, an effect that was maintained for up to 96 months of follow-up; OS was similar with both treatments $[32,56]$. Importantly, with prolonged bortezomib maintenance therapy for 96 months, there was no increased risk of second primary malignancies, which are an important complication for long-term survivors of MM [56]. A number of clinical trials to assess the use of newer agents (such as ixazomib, carfilzomib, elotuzumab, daratumumab, vorinostat, and panobinostat) for maintenance therapy are ongoing.

\section{Summary}

For transplant-eligible patients the goal is to achieve the deepest response and, if possible, a state of sustained minimal residual disease negativity. Consequently, use of a triplet regimen, such as VTD, VRd, or VCD, for induction prior to ASCT is recommended, providing toxicities allow. Owing to its potential to prolong PFS and OS, lenalidomide maintenance should be considered post-ASCT for all patients in whom it is tolerated. Additional clinical studies are needed to confirm the value of consolidation treatment after ASCT, as well as the use of newer therapies for maintenance [1].

\section{Transplant-ineligible patients}

While using the most effective agents is the main strategy for newly diagnosed, transplant-eligible patients, this is not always appropriate for transplant-ineligible patients, who are usually older and may be considered less fit owing to comorbidities, disability, or disease burden. As a result, regimens that are suitable for transplant-eligible patients may be associated with toxicity issues that lead to early treatment discontinuation, resulting in low efficacy and poor quality of life in transplant-ineligible patients [57]. For example, although data are preliminary, the doublet VD has been shown to be as effective as the triplets bortezomib, melphalan, and prednisone (VMP) and VTD, and is associated with reduced toxicity in transplant-ineligible patients [35]. Therapy in these patients frequently focuses on controlling symptoms and preserving vital organ function, performance status, and quality of life [57].

A number of studies have investigated the efficacy of triplet and doublet regimens in patients not eligible for ASCT (Table 2) [35, 58-65], and there is some evidence to suggest that the use of a doublet may be more appropriate than a triplet $[35,62,63]$. For example, improved PFS and OS were demonstrated in a phase 3 study comparing lenalidomide and lowdose dexamethasone (Rd) with melphalan, prednisone, and thalidomide (MPT) [63]. Furthermore, a phase 3 study 
Table 2 Key phase 3 studies of doublet and triplet regimens in transplant-ineligible patients with newly diagnosed multiple myeloma

\begin{tabular}{|c|c|c|c|c|c|c|c|}
\hline Study & Regimen & $N$ & ORR $(\%)$ & VGPR (\%) & CR $(\%)$ & $\begin{array}{l}\text { Median PFS } \\
\text { (months) }\end{array}$ & $\begin{array}{l}\text { Median OS } \\
\text { (months) }\end{array}$ \\
\hline \multirow[t]{2}{*}{ Palumbo [58] } & MP & 164 & - & 11 & 4 & 14.5 & 47.6 \\
\hline & MPT & 167 & - & 29 & 16 & 21.8 & 45.0 \\
\hline \multirow[t]{2}{*}{ Mateos [59] } & VMP & 130 & 80 & - & 20 & 34 & NR \\
\hline & VTP & 130 & 81 & - & 28 & 25 & NR \\
\hline \multirow[t]{3}{*}{ Niesvizky [35] } & VD & 168 & 73 & - & 3 & 14.7 & 49.8 \\
\hline & VTD & 167 & 80 & - & 4 & 15.4 & 51.5 \\
\hline & VMP & 167 & 70 & - & 4 & 17.3 & 53.1 \\
\hline \multirow[t]{2}{*}{ Stewart [60] } & MPT-T & 154 & 64 & 20 & 5 & 21.0 & 52.6 \\
\hline & MPR-R & 152 & 60 & 20 & 11 & 18.7 & 47.7 \\
\hline \multirow[t]{3}{*}{ Hungria [61] } & TD & 18 & 69 & 19 & 13 & 21.5 & 54.6 \\
\hline & CTD & 32 & 90 & 35 & 21 & 25.9 & 32.4 \\
\hline & MPT & 32 & 68 & 25 & 14 & 24.1 & 42.0 \\
\hline \multirow[t]{3}{*}{ Magarotto [62] } & $\mathrm{Rd}$ & 212 & 74 & 31 & 3 & 21.0 & NR \\
\hline & $\mathrm{CPR}$ & 220 & 68 & 20 & 1 & 20.0 & NR \\
\hline & MPR & 211 & 71 & 23 & 3 & 24.0 & NR \\
\hline \multirow[t]{3}{*}{ Hulin [63] } & Cont. Rd & 535 & 81 & 27 & 21 & 26.0 & 58.9 \\
\hline & Rd18 & 541 & 79 & 27 & 20 & 21.0 & 56.7 \\
\hline & MPT & 547 & 67 & 18 & 12 & 21.9 & 48.5 \\
\hline \multirow[t]{2}{*}{ Durie [64] } & $\mathrm{Rd}$ & 214 & 72 & 23 & 8 & 30.0 & 64.0 \\
\hline & VRd & 216 & 82 & 28 & 16 & 43.0 & 75.0 \\
\hline \multirow[t]{2}{*}{ Mateos [65] } & VMP & 356 & 74 & 25 & 24 & 18.1 & NR \\
\hline & DVMP & 350 & 91 & 29 & 43 & NR & NR \\
\hline
\end{tabular}

Cont. $R d$, continuous lenalidomide and low-dose dexamethasone; $C P R$, cyclophosphamide, prednisone, and lenalidomide; $C R$, complete response; $C T D$, cyclophosphamide, thalidomide, and dexamethasone; DVMP, daratumumab, bortezomib, melphalan, and prednisone; $M P$, melphalan and prednisone; $M P R$, melphalan, prednisone, and lenalidomide; $M P R-R$, melphalan, prednisone, and lenalidomide with lenalidomide maintenance; $M P T$, melphalan, prednisone, and thalidomide; $M P T-T$, MPT with thalidomide maintenance; $N R$, not reached; $O R R$, overall response rate; $O S$, overall survival; $P F S$, progression-free survival; $R d$, lenalidomide and low-dose dexamethasone; $R d 18$, lenalidomide and low-dose dexamethasone for 72 weeks ( 18 cycles $) ; T D$, thalidomide and dexamethasone; $V D$, bortezomib and dexamethasone; $V G P R$, very good partial response; $V M P$, bortezomib, melphalan, and prednisone; VTD, bortezomib, thalidomide, and dexamethasone; $V T P$, bortezomib, thalidomide, and prednisone demonstrated that triplet lenalidomide-based regimens (melphalan, prednisone, and lenalidomide (MPR) and cyclophosphamide, prednisone, and lenalidomide (CPR)) were not associated with a significant difference in PFS compared with $\mathrm{Rd}$ in elderly patients with NDMM [62]. However, for some patients, sequential regimens may be suitable and the use of VMP and Rd administered in either a sequential or an alternating manner has been shown to be feasible, producing a similar outcome (in terms of 18-month PFS) to the trials of continuous regimens reported so far [66]. Furthermore, the use of reduced intensity bortezomib-based triplet regimens (VMP or VTP) followed by maintenance with a doublet regimen of VT or VP has been shown to be effective and more tolerable than higher intensity treatment in elderly patients with NDMM; notably, VMP was associated with fewer serious adverse events than VTP [59]. However, there is evidence to suggest that some patients may benefit from a triplet regimen; the phase 3 SWOG S0777 study demonstrated that induction therapy with VRd improved PFS and OS, compared with Rd, and had an acceptable risk-benefit profile in patients with NDMM without intent for immediate ASCT [64]. Interestingly, recent data from the phase 3 ALCYONE study in transplant-ineligible patients show that, compared with VMP, addition of daratumumab to VMP resulted in significantly higher rates of complete response and 18-month PFS. However, the quadruplet regimen was associated with a higher rate of grade 3 or 4 infections compared with the triplet regimen [65].

When making treatment decisions for transplant-ineligible patients, it is important that factors such as patient age, comorbidities, degree of frailty, and patient preference are taken into account $[17,57,67,68]$. The International Myeloma Working Group (IMWG) recently developed a scoring system based on age, comorbidities, and cognitive and physical condition to 
classify patients in "fit," "intermediate-fit", and "frail" groups $[67,68]$. Management strategies can then be tailored accordingly (Fig. 1). For example, regimens consisting of two or three drugs at full dose may be appropriate for patients defined as fit, while those defined as intermediate-fit may be treated with two (or three) drugs at a reduced dose, and those defined as frail with one or two drugs at a significantly reduced dose $[17,57]$. In particular, CTD, MPT, CRD, Rd, VRd, or VMP may be suitable for fit or intermediate-fit patients [61, 69-71], while MP or cyclophosphamide and dexamethasone (CD) may be more appropriate for intermediate-fit or frail patients.

\section{Summary}

Many transplant-ineligible patients, and particularly those who are frail, are unlikely to tolerate aggressive combinations. Instead, a more conservative approach employing the use of reduced intensity combination or sequential treatments, that takes into consideration possible toxicity issues and likely tolerability, may be more appropriate in this group of patients. However, it is important to assess the fitness of transplantineligible patients because those who are 'fit' may be able to benefit from two- or three-drug regimens used at full dose.

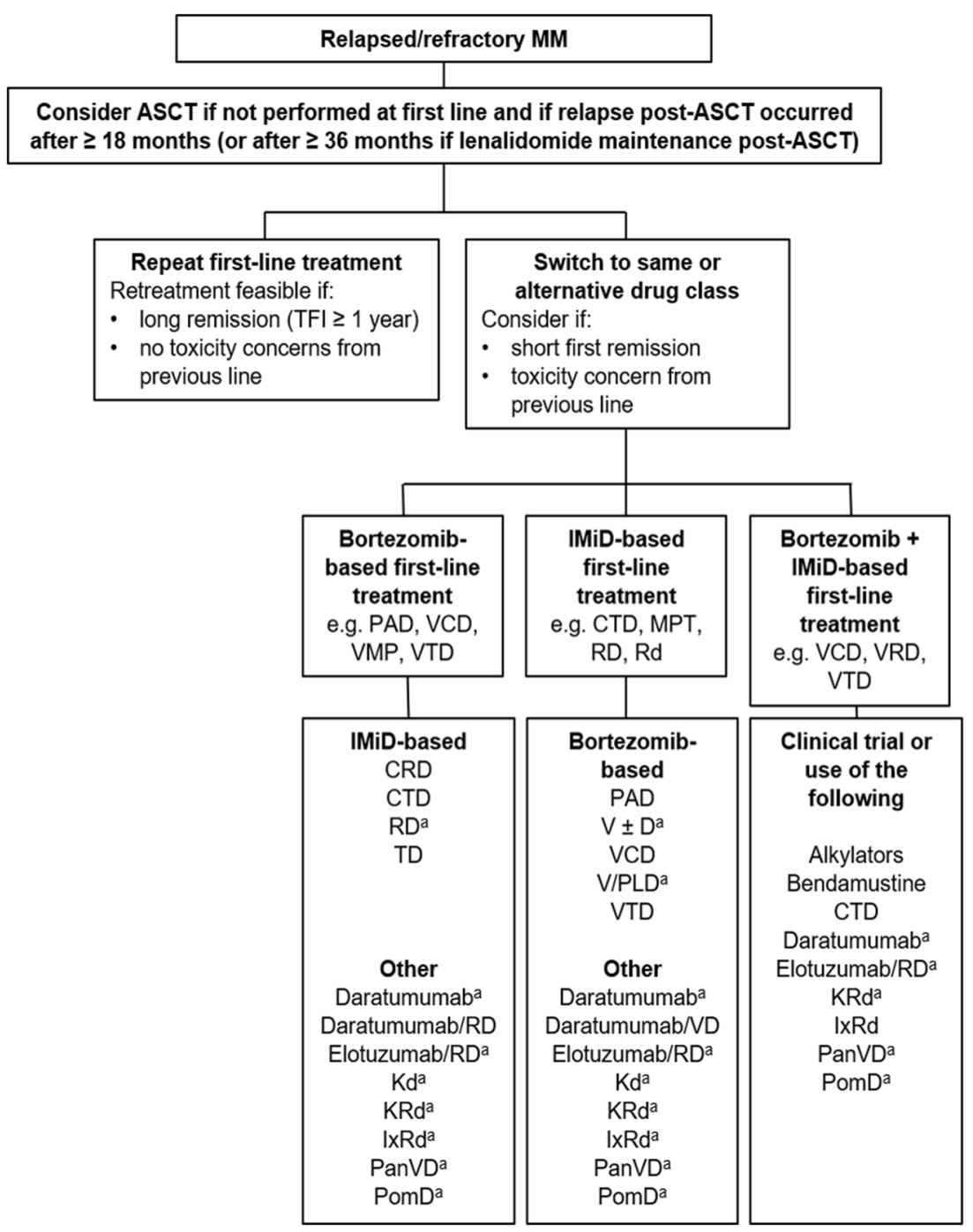

Fig. 2 Treatment algorithm for patients with relapsed/refractory multiple myeloma. ASCT, autologous stem cell transplantation; $C R D$, cyclophosphamide, lenalidomide, and dexamethasone; CTD, cyclophosphamide, thalidomide, and dexamethasone; IMiD, immunomodulatory drug; $I x R d$, ixazomib, lenalidomide, and low-dose dexamethasone; $K d$, carfilzomib and low-dose dexamethasone; $K R d$, carfilzomib, lenalidomide, and low-dose dexamethasone; $M M$, multiple myeloma; $M P T$, melphalan, prednisone, and thalidomide; $P A D$, bortezomib, doxorubicin, and dexamethasone; PanVD, panobinostat, bortezomib, and dexamethasone; PomD, pomalidomide and dexamethasone; $R d$, lenalidomide and low-dose dexamethasone; $R D$, lenalidomide and high-dose dexamethasone; $T D$, thalidomide and dexamethasone; TFI, treatment-free interval; $V C D$, bortezomib, cyclophosphamide, and dexamethasone; $V \pm D$, bortezomib with or without dexamethasone; $V M P$, bortezomib, melphalan, and prednisone; V/PLD, bortezomib and pegylated liposomal doxorubicin; $V R D$, bortezomib, lenalidomide, and dexamethasone; VTD, bortezomib, thalidomide, and dexamethasone. ${ }^{a}$ Therapies approved by the European Medicines Agency 
Table 3 Key phase 3 studies of doublet and triplet regimens in patients with relapsed and/or refractory multiple myeloma

\begin{tabular}{|c|c|c|c|c|c|c|c|}
\hline Study & Regimen & $N$ & ORR $(\%)$ & $\begin{array}{l}\text { VGPR } \\
(\%)\end{array}$ & $\begin{array}{l}\text { CR } \\
(\%)\end{array}$ & $\begin{array}{l}\text { Median } \\
\text { PFS } \\
\text { (months) }\end{array}$ & $\begin{array}{l}\text { Median } \\
\text { OS } \\
\text { (months) }\end{array}$ \\
\hline \multirow[t]{2}{*}{ Garderet [79] } & $\mathrm{TD}$ & 134 & 72 & 14 & 13 & 13.6 & - \\
\hline & VTD & 135 & 87 & 11 & 28 & 18.3 & - \\
\hline \multirow[t]{2}{*}{ San-Miguel [14] } & VD & 381 & 55 & - & 6 & 8.1 & 30.4 \\
\hline & PanVD & 387 & 61 & - & 11 & 12.0 & 33.6 \\
\hline \multirow[t]{2}{*}{ Baz [80] } & PomD & 36 & 39 & - & - & 4.4 & 10.5 \\
\hline & PCD & 34 & 65 & - & - & 9.2 & 16.4 \\
\hline \multirow[t]{2}{*}{ Stewart [7] } & $\mathrm{Rd}$ & 396 & 67 & 40 & 5 & 17.6 & NR \\
\hline & $\mathrm{KRd}$ & 396 & 87 & 70 & 18 & 26.3 & NR \\
\hline \multirow[t]{2}{*}{ Lonial [9] } & $\mathrm{Rd}$ & 325 & 66 & 21 & 7 & 14.9 & NR \\
\hline & Rd + elotuzumab & 321 & 79 & 28 & 4 & 19.4 & NR \\
\hline \multirow[t]{2}{*}{ Moreau [10] } & $\mathrm{Rd}$ & 362 & 72 & 32 & 7 & 14.7 & NR \\
\hline & IxRd & 360 & 78 & 36 & 12 & 20.6 & NR \\
\hline \multirow[t]{2}{*}{ Palumbo [15] } & $\mathrm{Vd}$ & 247 & 63 & 20 & 7 & 7.2 & - \\
\hline & $\mathrm{Vd}+$ daratumumab & 251 & 83 & 40 & 15 & NR & - \\
\hline \multirow[t]{2}{*}{ Dimopoulos $[4,8]$} & $\mathrm{Kd}$ & 464 & 77 & 42 & 13 & 18.7 & 47.6 \\
\hline & $\mathrm{Vd}$ & 465 & 63 & 22 & 6 & 9.4 & 40.0 \\
\hline \multirow[t]{2}{*}{ Dimopoulos [16] } & $\mathrm{Rd}$ & 283 & 76 & 25 & 19 & 18.4 & - \\
\hline & $\mathrm{Rd}+$ daratumumab & 286 & 93 & 33 & 43 & NR & - \\
\hline
\end{tabular}

$C R$, complete response; $I x R d$, ixazomib, lenalidomide, and low-dose dexamethasone; $K d$, carfilzomib and lowdose dexamethasone; $K R d$, carfilzomib, lenalidomide, and low-dose dexamethasone; $N R$, not reached; $O R R$, overall response rate; $O S$, overall survival; PanVD, panobinostat, bortezomib, and dexamethasone; $P C D$, pomalidomide, cyclophosphamide, and dexamethasone; $P F S$, progression-free survival; PomD, pomalidomide and dexamethasone; $R d$, lenalidomide and low-dose dexamethasone; $T D$, thalidomide and dexamethasone; $V d$, bortezomib and low-dose dexamethasone; $V D$, bortezomib and dexamethasone; $V G P R$, very good partial response; VTD, bortezomib, thalidomide, and dexamethasone

\section{Management of patients with relapsed/ refractory multiple myeloma}

Relapse of MM is considered to be almost inevitable and the management of patients with RRMM requires an individualized approach. This should take into account the patient's age, fitness, comorbidities, treatment history (including both depth and duration of the response, as well as treatment toxicities), and aggressiveness of the relapse, as well as the expectations of the patient and his or her quality of life [17, 72, 73]. Treatment options include re-treating with an agent used previously, switching to a different agent in the same drug class, or switching to an agent in a different drug class (Fig. 2). ASCT may be considered as a salvage option if patients are transplant-eligible and have either never received an ASCT or had a previous ASCT with a long response duration [73-77]. Patients should also be considered for participation in clinical trials, if available [17, 72, 73, 78].

In general, doublet or triplet regimens are used in RRMM (Table 3) [7-10, 14-16, 79, 80], with the specific treatment choice dependent upon the expected efficacy, toxicity, and possible cost considerations, as well as the fitness of the patient $[17,72,78]$. Bortezomib, thalidomide, and lenalidomide were frequently used for the treatment of RRMM $[17,72,73]$. For example, combinations such as VTD, VRD, VCD, and bortezomib with doxorubicin and dexamethasone (PAD) may still be considered; in particular, the triplet VTD has been shown to be superior to TD in patients with relapsed disease post ASCT $[17,79]$. However, the presence of comorbidities such as PN may mean that changes are made to the dose or schedule, or necessitate use of an alternative drug class [72, $78,81]$. Rd is also an effective option [72, 82, 83] and TD may be appropriate, especially if patients are thalidomide-naïve or are not eligible for bortezomib or lenalidomide-based treatment [72].

The development of novel agents for the treatment of MM has significantly increased the range of possible treatment combinations and these may result in even better outcomes for patients with RRMM. KRd has been shown to have a significant impact on PFS and OS, with a favorable riskbenefit profile and improved health-related quality of life compared with $\mathrm{Rd}[7,84]$. The benefit of this regimen in terms of PFS was observed in all patients, including those who had previously received treatment with bortezomib or lenalidomide or who had high-risk cytogenetics. The combination of carfilzomib with low-dose dexamethasone $(\mathrm{Kd})$ has 
also been shown to result in improved PFS and OS compared with bortezomib combined with low-dose dexamethasone (Vd) $[4,8]$. PN has been shown to be less frequent in patients treated with carfilzomib than in those receiving bortezomib, and addition of carfilzomib to Rd did not add PN toxicity, so carfilzomib regimens may be a suitable option for patients including those with existing or anticipated neuropathy $[8$, 78].

Another second-generation proteasome inhibitor, ixazomib, has been developed, and the combination of ixazomib with lenalidomide and low-dose dexamethasone has been shown to result in improved PFS compared with placebo, lenalidomide, and low-dose dexamethasone in patients with RRMM [10]. Ixazomib is available in the USA and received approval for use in Europe in December 2016 $[10,85]$. In addition, the availability of the immunomodulatory agent pomalidomide and the HDAC inhibitor panobinostat has opened up the possibility of using doublet or triplet regimens in patients with advanced disease [11, 12, 14]. In particular, pomalidomide in combination with dexamethasone is suitable for use in patients who have received at least two previous treatment regimens and have demonstrated disease progression $[12,86]$. Studies investigating the use of pomalidomide, bortezomib, and dexamethasone (PVd), pomalidomide, cyclophosphamide, and prednisone (PCP), pomalidomide, cyclophosphamide, and dexamethasone (PCD) and pomalidomide, carfilzomib, and dexamethasone (PKD), also suggest that these regimens may be effective in RRMM [11, 80, 87, 88]. Additionally, although not currently approved in the relapsed setting, the alkylating agent bendamustine in combination with thalidomide and dexamethasone has been shown to be a viable salvage therapy for patients with relapsed disease who are refractory to bortezomib and lenalidomide [13].

The use of monoclonal antibodies is well established for the treatment of other cancers and although these agents have only recently become available for the treatment of RRMM, they are already showing promise. The anti-CD38 monoclonal antibody daratumumab has been shown to be effective in patients with RRMM in a number of studies, either as monotherapy or in combination with lenalidomide and dexamethasone $[89,90]$. In addition, results from a phase 3 trial of daratumumab with bortezomib and dexamethasone (CASTOR) demonstrated a significant improvement in PFS compared with bortezomib and dexamethasone alone [15]; PFS was also found to be improved in patients treated with daratumumab, lenalidomide, and dexamethasone versus those who received lenalidomide and dexamethasone only (POLLUX) [16]. In addition, the anti-SLAM-7 antibody elotuzumab combined with lenalidomide and dexamethasone was associated with improved PFS in patients with RRMM compared with lenalidomide and dexamethasone alone [9]. Results from a phase 2 study also indicate improved PFS in patients treated with elotuzumab, bortezomib, and dexamethasone versus those treated with bortezomib and dexamethasone alone [91]. These findings suggest that monoclonal antibodies will have an important role in the future treatment of patients with RRMM, and several ongoing trials are assessing their value when combined with other therapeutic agents [92-95].

When making treatment decisions, the prognosis may influence the therapeutic strategy chosen. For example, recent recommendations from the IMWG suggest that patients with a poor prognosis at relapse are treated with a triplet or quadruplet regimen, until disease progression [73]. In this setting, novel treatments may be more appropriate than bortezomib or alkylating agents, because these agents are suitable for use until disease progression [54, 85, 96, 97]. In contrast, it is recommended that patients with indolent disease characteristics are treated with one- or two-drug regimens and treatment-free intervals may be appropriate for these individuals [73]. In addition, existing comorbidities may make it necessary to consider dose adjustments, for example reduced doses of ixazomib and lenalidomide are recommended for patients with severe renal impairment [54, 85].

The response to previous therapies must also be taken into account when making treatment decisions. Re-treatment with a drug used previously should be feasible, provided that a clinically meaningful response was achieved, the previous response lasted for at least 12 months, and treatment was associated with acceptable toxicity $[17,72,78]$. In patients who demonstrate disease progression while on therapy, or who had only a short response, switching to a different drug class should be considered [73]. For example, if lenalidomide was used as first-line treatment, bortezomib could be used at relapse. Alternatively, it may be possible to use a second-generation agent in the same drug class as the treatment used at first line. For example, carfilzomib is structurally and mechanistically distinct from bortezomib and has been shown to be effective in patients who previously received bortezomib [7, 8]. In addition, studies have demonstrated that pomalidomide is effective in patients for whom lenalidomide has failed [98], as well as in those who are refractory to both lenalidomide and bortezomib [12,99]. Given the number of novel agents now available in both existing and new drug classes, it should be possible for patients to receive treatment at relapse with an agent that they are not resistant to, even if they receive a combination treatment initially. However, long-term data on the use of the newest agents following different initial treatment combinations are limited and so further studies will be needed to determine whether particular sequences of drug regimens are associated with improved responses and long-term outcomes.

\section{Summary}

In the relapse setting, triplet regimens including lenalidomide, dexamethasone, and either a monoclonal antibody or a proteasome inhibitor are recommended, although this may 
Table 4 High-risk disease characteristics in multiple myeloma [73, 102-104]

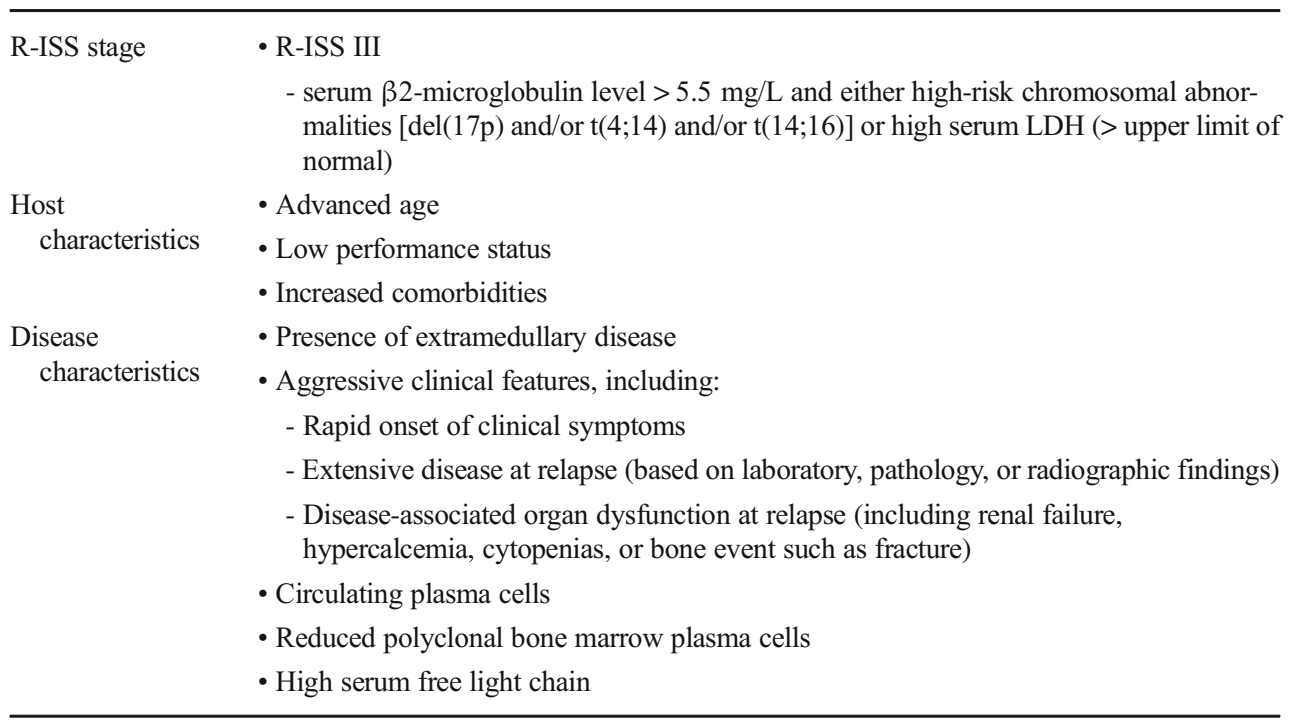

$L D H$, lactate dehydrogenase; $R$-ISS, revised International Staging System depend on the therapies employed at first line. If a bortezomib-based regimen was used at first line, a lenalidomide-based regimen can be used at relapse and vice versa. Regimens employing the next-generation immunomodulatory drug pomalidomide are currently under investigation and are likely to prove useful for patients with RRMM [100, $101]$.

\section{Considerations for patients with standard-risk versus high-risk disease}

Although response to treatment and survival of patients with $\mathrm{MM}$ is highly variable, there are certain prognostic factors that can be used to predict the clinical course of the disease [1]. Patients can be stratified into high-risk and standard-risk disease groups according to the presence or absence of various disease characteristics such as cytogenetic abnormalities, elevated serum $\beta 2$-microglobulin levels, and elevated serum lactate dehydrogenase levels (Table 4) [73, 102-104]. Treatment decisions can then be made on the basis of these risk classifications.

In general, patients with high-risk disease (including high-risk cytogenetics and/or high tumor load) should be treated with a triplet regimen, if possible. Trials studying the use of thalidomide during induction therapy in transplant-eligible patients with NDMM indicate that this therapy does not overcome the adverse prognosis associated with high-risk cytogenetics [26, 31, 103, 105]. However, patients with $\mathrm{t}(4 ; 14)$ may benefit from a proteasome inhibitor-based treatment, and the combination of a proteasome inhibitor with lenalidomide and dexamethasone has been recommended by the IMWG for newly diagnosed transplant-eligible patients with high-risk cytogenetics [103, 106]. Results from a recent post hoc analysis suggest that cytogenetic risk should also be taken into account in the context of sequential therapy. While PFS at second line (PFS2) was not influenced by treatment sequence in patients with standard-risk cytogenetics, PFS2 was reduced in individuals with high-risk cytogenetics who received lenalidomide upfront followed by bortezomib at first relapse, compared with those who received the same treatment at relapse or who received bortezomib upfront [107]. In addition, double high-dose therapy/ASCT combined with bortezomib may improve PFS in patients with high-risk cytogenetics $(t(4 ; 14)$ or $\operatorname{del}(17 p))$ [103].

In patients with RRMM and high-risk disease, doublet therapy consisting of pomalidomide plus low-dose dexamethasone may be a suitable option $[73,108]$; in particular, this therapy option has been shown to be active in patients with del(17p) [109]. The phase 3 trials of KRd and Kd in patients with RRMM suggest that carfilzomib is also effective in patients with high-risk cytogenetics $[7,8,110]$. Similarly, subgroup analysis of the phase 3 TOURMALINE-MM1 trial of ixazomib plus Rd suggest that this combination is effective in patients with high-risk cytogenetics [40]. Additionally, recent subgroup analyses of the phase 3 POLLUX and CASTOR trials suggest that, compared with control treatment, daratumumab improves response rates and PFS in patients with high-risk disease and in those with standard-risk disease $[111,112]$. One other option for high-risk patients with relapsed MM is allogeneic stem cell transplantation. However, this is suitable only for a subset of patients who are young and who have an available human leukocyte antigen-matched donor, chemotherapy-sensitive disease, and an excellent performance status, and it should ideally be performed in the context of a clinical trial [73]. 


\section{Summary}

The treatment of patients with high-risk disease with a triplet regimen including a proteasome inhibitor and an immunomodulatory drug is recommended. A triplet regimen, perhaps including the novel immunomodulatory drug pomalidomide or a proteasome inhibitor such as carfilzomib, may be an option for patients with RRMM and high-risk disease.

\section{Future treatment strategies}

Multiple myeloma should not be considered to be one disease, but rather a mix of different disease entities that further interact with individual patient characteristics [102]. Risk stratification is crucial to identify patients with a high risk of early relapse in order to adapt treatment regimens accordingly; however, further work is required to develop tools that take into account the broad spectrum of factors that define risk, both in the front-line and relapsed settings $[102,113]$. Beyond risk stratification, the advent of various highthroughput technologies in myeloma cell genotyping and phenotyping are bringing personalized myeloma therapy ever closer. Gene expression profiling of malignant plasma cells is a promising method for prognostication and may inform treatment choices [114-116]. For example, the presence of NRAS mutations has been shown to be associated with poor response to bortezomib [117]. Conversely, mutations in IRF4 are associated with favorable outcomes following immunomodulatory agent therapy [118]. Finally, the identification of novel mutations may lead to the development of new targeted therapies in myeloma [118]. For example, overexpression of BCL-2 has been implicated in the growth of $t(11 ; 14)$ myeloma cells and preliminary results from a phase 1 study suggest that the BCL-2 inhibitor venetoclax may be effective in treating patients with $\mathrm{t}(11 ; 14)$ [119].

Given the array of therapeutic options available and the efficacy of triplet regimens, it might be expected that use of quadruplet regimens would result in even better outcomes. The efficacy and safety of quadruplet regimens have been investigated in a limited number of studies; although preliminary data suggest that the quadruplet CCRD is effective [43], studies of other quadruplet regimens have reported toxicity issues [120]. Further studies will be needed to assess the value of these regimens. A number of phase 3 studies assessing the value of quadruplet regimens including a monoclonal antibody are ongoing [121, 122].

Other new therapeutic agents are under investigation, including novel proteasome inhibitors (oprozomib and marizomib), HDAC inhibitors (romidepsin, vorinostat, ricolinostat), monoclonal antibodies (SAR650984, MOR202, isatuximab, ipilimumab), and small-molecule inhibitors (vemurafenib, venetoclax, CPI-0610, LGH447, dinaciclib, selinexor, ibrutinib, and filanesib) $[6,23,95$, 123]. The efficacy of these remains to be fully tested; however, they should help to expand the range of therapeutic options available. This is particularly important because the use of combination therapies at first line increases the risk of developing resistance to multiple classes of drug, necessitating the use of different agents at later lines. In addition, the use of existing therapies has already been shown to be associated with high costs [124], and it is likely that novel agents will increase these further, placing a significant burden on healthcare providers and funding bodies. As more novel agents emerge, cost-effectiveness analyses will be needed to establish the value of adopting combination regimens. Nonetheless, it seems probable that the development of new treatments is likely to result in improvements in the long-term management of patients with MM and raises the possibility that in the future it may be possible to cure the disease, particularly in patients who are able to tolerate combination therapy with a range of different agents.

\section{Conclusions}

The treatment landscape for MM has evolved significantly over the past decade, and several therapeutic options are now available. In particular, the development and availability of monoclonal antibodies may well lead to a treatment paradigm shift whereby the use of a monoclonal antibody in combination with a doublet or triplet regimen may be suitable for treatment of the disease. Of course, the heterogeneity of MM means that an individualized approach is still required when making treatment decisions. This should involve risk stratification and the assessment of the patient's frailty, disabilities, and comorbidities and, in the RRMM setting, consideration of previous treatment history and response.

The availability of novel agents makes combinations of drugs from different classes possible, and the latest results from clinical studies suggest that the efficacy benefits of treatment combinations involving these agents are likely to outweigh the risk of patients developing multi-drug resistance. However, it remains important for physicians to consider the aims of treatment carefully, and to ensure that there is an appropriate balance between response and toxicity. There is also a need to investigate novel treatment combinations and sequences further, with the aim of achieving greater responses while minimizing treatment-related toxicity, as well as the potential benefits of treating patients with high-risk smoldering MM. Additional work in these areas should ultimately lead to improved treatment regimens and outcomes for patients with MM.

Acknowledgements The authors would like to thank Laura Pearce, $\mathrm{PhD}$, from Oxford PharmaGenesis, Oxford, UK, who provided medical writing support and Emma Booth and Sarah Petrig from Amgen (Europe) GmbH 
for their editorial support. Medical writing support was funded by Amgen (Europe) $\mathrm{GmbH}$.

Authors' contributions HG made a substantial contribution to conception of the article, was involved with developing the draft of the article and revising it critically for important intellectual content, approved the final manuscript as submitted, and agrees to be accountable for all aspects of the work. JA made a substantial contribution to conception of the article, was involved with developing the draft of the article and revising it critically for important intellectual content, approved the final manuscript as submitted, and agrees to be accountable for all aspects of the work. ZS made a substantial contribution to conception of the article, was involved with developing the draft of the article and revising it critically for important intellectual content, approved the final manuscript as submitted, and agrees to be accountable for all aspects of the work. LG made a substantial contribution to conception of the article, was involved with developing the draft of the article and revising it critically for important intellectual content, approved the final manuscript as submitted, and agrees to be accountable for all aspects of the work.

\section{Compliance with ethical standards}

Conflict of interest HG has received research support from BristolMyers Squibb, Celgene Ltd., Chugai, Janssen, Millenium Pharmaceuticals, Inc., and Novartis International AG, has participated in advisory boards for Amgen, Bristol-Myers Squibb, Celgene Ltd., Janssen, Novartis International AG, Onyx Pharmaceuticals, Inc., and Takeda, and has received honoraria from Celgene Ltd., Chugai, Janssen, Millenium Pharmaceuticals, Inc., Novartis International AG, and Onyx Pharmaceuticals, Inc. JA has participated in advisory boards and as a consultant for Amgen, Celgene Ltd., Janssen, and Takeda. ZS is an employee of Amgen and holds stock. LG is a consultant for Amgen, Novartis International AG, and Takeda.

Open Access This article is distributed under the terms of the Creative Commons Attribution 4.0 International License (http:// creativecommons.org/licenses/by/4.0/), which permits unrestricted use, distribution, and reproduction in any medium, provided you give appropriate credit to the original author(s) and the source, provide a link to the Creative Commons license, and indicate if changes were made.

\section{References}

1. Moreau P, San Miguel J, Sonneveld P, Mateos MV, Zamagni E, Avet-Loiseau H, Hajek R, Dimopoulos MA, Ludwig H, Einsele H, Zweegman S, Facon T, Cavo M, Terpos E, Goldschmidt H, Attal M, Buske C, ESMO Guidelines Committee (2017) Multiple myeloma: ESMO clinical practice guidelines for diagnosis, treatment and follow-up. Ann Oncol 28:iv52-iv61. https://doi.org/10. 1093/annonc/mdx096

2. Kumar SK, Rajkumar SV, Dispenzieri A, Lacy MQ, Hayman SR, Buadi FK, Zeldenrust SR, Dingli D, Russell SJ, Lust JA, Greipp PR, Kyle RA, Gertz MA (2008) Improved survival in multiple myeloma and the impact of novel therapies. Blood 111(5):2516 2520. https://doi.org/10.1182/blood-2007-10-116129

3. Kumar SK, Dispenzieri A, Lacy MQ, Gertz MA, Buadi FK, Pandey S, Kapoor P, Dingli D, Hayman SR, Leung N, Lust J, McCurdy A, Russell SJ, Zeldenrust SR, Kyle RA, Rajkumar SV (2014) Continued improvement in survival in multiple myeloma: changes in early mortality and outcomes in older patients.
Leukemia 28(5):1122-1128. https://doi.org/10.1038/leu.2013. 313

4. Dimopoulos MA, Goldschmidt H, Niesvizky R, Joshua D, Chng WJ, Oriol A, Orlowski RZ, Ludwig H, Facon T, Hajek R, Weisel K, Hungria V, Minuk L, Feng S, Zahlten-Kumeli A, Kimball AS, Moreau P (2017) Carfilzomib or bortezomib in relapsed or refractory multiple myeloma (ENDEAVOR): an interim overall survival analysis of an open-label, randomised, phase 3 trial. Lancet Oncol 18(10):1327-1337. https://doi.org/10.1016/S1470-2045(17) 30578-8

5. Larsen JT, Kumar S (2015) Evolving paradigms in the management of multiple myeloma: novel agents and targeted therapies. Rare Cancers Ther 3:47-68. https://doi.org/10.1007/s40487-0150009-4

6. Ocio EM, Richardson PG, Rajkumar SV, Palumbo A, Mateos MV, Orlowski R, Kumar S, Usmani S, Roodman D, Niesvizky R, Einsele H, Anderson KC, Dimopoulos MA, Avet-Loiseau H, Mellqvist UH, Turesson I, Merlini G, Schots R, McCarthy P, Bergsagel L, Chim CS, Lahuerta JJ, Shah J, Reiman A, Mikhael J, Zweegman S, Lonial S, Comenzo R, Chng WJ, Moreau P, Sonneveld P, Ludwig H, Durie BG, Miguel JF (2014) New drugs and novel mechanisms of action in multiple myeloma in 2013: a report from the International Myeloma Working Group (IMWG). Leukemia 28(3):525-542. https://doi.org/10.1038/leu.2013.350

7. Stewart AK, Rajkumar SV, Dimopoulos MA, Masszi T, Spicka I, Oriol A, Hajek R, Rosinol L, Siegel DS, Mihaylov GG, Goranova-Marinova V, Rajnics P, Suvorov A, Niesvizky R, Jakubowiak AJ, San-Miguel JF, Ludwig H, Wang M, Maisnar V, Minarik J, Bensinger WI, Mateos MV, Ben-Yehuda D, Kukreti V, Zojwalla N, Tonda ME, Yang X, Xing B, Moreau P, Palumbo A, Aspire Investigators (2015) Carfilzomib, lenalidomide, and dexamethasone for relapsed multiple myeloma. N Engl J Med 372(2):142-152. https://doi.org/10.1056/ NEJMoa1411321

8. Dimopoulos MA, Moreau P, Palumbo A, Joshua D, Pour L, Hajek R, Facon T, Ludwig H, Oriol A, Goldschmidt H, Rosinol L, Straub J, Suvorov A, Araujo C, Rimashevskaya E, Pika T, Gaidano G, Weisel K, Goranova-Marinova V, Schwarer A, Minuk L, Masszi T, Karamanesht I, Offidani M, Hungria V, Spencer A, Orlowski RZ, Gillenwater HH, Mohamed N, Feng S, Chng WJ, Endeavor Investigators (2016) Carfilzomib and dexamethasone versus bortezomib and dexamethasone for patients with relapsed or refractory multiple myeloma (ENDEAVOR): a randomised, phase 3, open-label, multicentre study. Lancet Oncol 17(1):27-38. https://doi.org/10.1016/S14702045(15)00464-7

9. Lonial S, Dimopoulos M, Palumbo A, White D, Grosicki S, Spicka I, Walter-Croneck A, Moreau P, Mateos MV, Magen H, Belch A, Reece D, Beksac M, Spencer A, Oakervee H, Orlowski RZ, Taniwaki M, Rollig C, Einsele H, Wu KL, Singhal A, San-Miguel J, Matsumoto M, Katz J, Bleickardt E, Poulart V, Anderson KC, Richardson P, Eloquent Investigators (2015) Elotuzumab therapy for relapsed or refractory multiple myeloma. N Engl J Med 373(7): 621-631. https://doi.org/10.1056/NEJMoa1505654

10. Moreau P, Masszi T, Grzasko N, Bahlis NJ, Hansson M, Pour L, Sandhu I, Ganly P, Baker BW, Jackson SR, Stoppa AM, Simpson DR, Gimsing P, Palumbo A, Garderet L, Cavo M, Kumar S, Touzeau C, Buadi FK, Laubach JP, Berg DT, Lin J, Di Bacco A, Hui AM, van de Velde H, Richardson PG, Tourmaline-MM Study Group (2016) Oral ixazomib, lenalidomide, and dexamethasone for multiple myeloma. N Engl J Med 374(17):1621-1634. https:// doi.org/10.1056/NEJMoa1516282

11. Larocca A, Montefusco V, Bringhen S, Rossi D, Crippa C, Mina R, Galli M, Marcatti M, La Verde G, Giuliani N, Magarotto V, Guglielmelli T, Rota-Scalabrini D, Omede P, Santagostino A, Baldi I, Carella AM, Boccadoro M, Corradini P, Palumbo A 
(2013) Pomalidomide, cyclophosphamide, and prednisone for relapsed/refractory multiple myeloma: a multicenter phase $1 / 2$ open-label study. Blood 122(16):2799-2806. https://doi.org/10. 1182/blood-2013-03-488676

12. San Miguel J, Weisel K, Moreau P, Lacy M, Song K, Delforge M, Karlin L, Goldschmidt H, Banos A, Oriol A, Alegre A, Chen C, Cavo M, Garderet L, Ivanova V, Martinez-Lopez J, Belch A, Palumbo A, Schey S, Sonneveld P, Yu X, Sternas L, Jacques C, Zaki M, Dimopoulos M (2013) Pomalidomide plus low-dose dexamethasone versus high-dose dexamethasone alone for patients with relapsed and refractory multiple myeloma (MM-003): a randomised, open-label, phase 3 trial. Lancet Oncol 14(11): 1055-1066. https://doi.org/10.1016/S1470-2045(13)70380-2

13. Lau IJ, Smith D, Aitchison R, Blesing N, Roberts P, Peniket A, Yong K, Rabin N, Ramasamy K (2015) Bendamustine in combination with thalidomide and dexamethasone is a viable salvage option in myeloma relapsed and/or refractory to bortezomib and lenalidomide. Ann Hematol 94(4):643-649. https://doi.org/10. 1007/s00277-014-2238-2

14. San-Miguel JF, Hungria VT, Yoon SS, Beksac M, Dimopoulos MA, Elghandour A, Jedrzejczak WW, Gunther A, Nakorn TN, Siritanaratkul N, Corradini P, Chuncharunee S, Lee JJ, Schlossman RL, Shelekhova T, Yong K, Tan D, Numbenjapon T, Cavenagh JD, Hou J, LeBlanc R, Nahi H, Qiu L, Salwender H, Pulini S, Moreau P, Warzocha K, White D, Blade J, Chen W, de la Rubia J, Gimsing P, Lonial S, Kaufman JL, Ocio EM, Veskovski L, Sohn SK, Wang MC, Lee JH, Einsele H, Sopala M, Corrado C, Bengoudifa BR, Binlich F, Richardson PG (2014) Panobinostat plus bortezomib and dexamethasone versus placebo plus bortezomib and dexamethasone in patients with relapsed or relapsed and refractory multiple myeloma: a multicentre, randomised, double-blind phase 3 trial. Lancet Oncol 15(11): 1195-1206. https://doi.org/10.1016/S1470-2045(14)70440-1

15. Palumbo A, Chanan-Khan A, Weisel K, Nooka AK, Masszi T, Beksac M, Spicka I, Hungria V, Munder M, Mateos MV, Mark TM, Qi M, Schecter J, Amin H, Qin X, Deraedt W, Ahmadi T, Spencer A, Sonneveld P, CASTOR Investigators (2016) Daratumumab, bortezomib, and dexamethasone for multiple myeloma. N Engl J Med 375(8):754-766. https://doi.org/10.1056/ NEJMoa1606038

16. Dimopoulos MA, Oriol A, Nahi H, San-Miguel J, Bahlis NJ, Usmani SZ, Rabin N, Orlowski RZ, Komarnicki M, Suzuki K, Plesner T, Yoon SS, Ben Yehuda D, Richardson PG, Goldschmidt H, Reece D, Lisby S, Khokhar NZ, O'Rourke L, Chiu C, Qin X, Guckert M, Ahmadi T, Moreau P, POLLUX Investigators (2016) Daratumumab, lenalidomide, and dexamethasone for multiple myeloma. N Engl J Med 375(14):1319-1331. https://doi.org/10. 1056/NEJMoa1607751

17. Ludwig H, Sonneveld P, Davies F, Blade J, Boccadoro M, Cavo M, Morgan G, de la Rubia J, Delforge M, Dimopoulos M, Einsele H, Facon T, Goldschmidt H, Moreau P, Nahi H, Plesner T, SanMiguel J, Hajek R, Sondergeld P, Palumbo A (2014) European perspective on multiple myeloma treatment strategies in 2014. Oncologist 19(8):829-844. https://doi.org/10.1634/theoncologist. 2014-0042

18. Nooka A, Lonial S (2012) Sequential or combination therapy for multiple myeloma. Expert Rev Hematol 5(5):533-545. https://doi. org/10.1586/ehm.12.49

19. Keats JJ, Chesi M, Egan JB, Garbitt VM, Palmer SE, Braggio E, Van Wier S, Blackburn PR, Baker AS, Dispenzieri A, Kumar S, Rajkumar SV, Carpten JD, Barrett M, Fonseca R, Stewart AK, Bergsagel PL (2012) Clonal competition with alternating dominance in multiple myeloma. Blood 120(5):1067-1076. https://doi. org/10.1182/blood-2012-01-405985

20. Altun M, Galardy PJ, Shringarpure R, Hideshima T, LeBlanc R, Anderson KC, Ploegh HL, Kessler BM (2005) Effects of PS-341 on the activity and composition of proteasomes in multiple myeloma cells. Cancer Res 65(17):7896-7901. https://doi.org/10. 1158/0008-5472.can-05-0506

21. Anderson KC (2012) The 39th David A. Karnofsky lecture: bench-tobedside translation of targeted therapies in multiple myeloma. J Clin Oncol 30(4):445-452. https://doi.org/10.1200/jco.2011.37.8919

22. van de Donk NW, Janmaat ML, Mutis T, Lammerts van Bueren JJ, Ahmadi T, Sasser AK, Lokhorst HM, Parren PW (2016) Monoclonal antibodies targeting CD38 in hematological malignancies and beyond. Immunol Rev 270(1):95-112. https://doi. org/10.1111/imr.12389

23. Cornell RF, Kassim AA (2016) Evolving paradigms in the treatment of relapsed/refractory multiple myeloma: increased options and increased complexity. Bone Marrow Transplant 51(4):479491. https://doi.org/10.1038/bmt.2015.307

24. Engelhardt M, Terpos E, Kleber M, Gay F, Wasch R, Morgan G, Cavo M, van de Donk N, Beilhack A, Bruno B, Johnsen HE, Hajek R, Driessen C, Ludwig H, Beksac M, Boccadoro M, Straka C, Brighen S, Gramatzki M, Larocca A, Lokhorst H, Magarotto V, Morabito F, Dimopoulos MA, Einsele H, Sonneveld P, Palumbo A, European Myeloma Network (2014) European myeloma network recommendations on the evaluation and treatment of newly diagnosed patients with multiple myeloma. Haematologica 99(2):232-242. https://doi.org/10.3324/ haematol.2013.099358

25. Palumbo A, Gay F, Bringhen S, Falcone A, Pescosta N, Callea V, Caravita T, Morabito F, Magarotto V, Ruggeri M, Avonto I, Musto P, Cascavilla N, Bruno B, Boccadoro M (2008) Bortezomib, doxorubicin and dexamethasone in advanced multiple myeloma. Ann Oncol 19(6):1160-1165. https://doi.org/10.1093/annonc/ mdn018

26. Morgan GJ, Davies FE, Gregory WM, Russell NH, Bell SE, Szubert AJ, Navarro Coy N, Cook G, Feyler S, Byrne JL, Roddie H, Rudin C, Drayson MT, Owen RG, Ross FM, Jackson GH, Child JA, NCRI Haematological Oncology Study Group (2011) Cyclophosphamide, thalidomide, and dexamethasone (CTD) as initial therapy for patients with multiple myeloma unsuitable for autologous transplantation. Blood 118(5):1231-1238. https://doi.org/10.1182/blood-2011-02-338665

27. Cavo M, Tacchetti P, Patriarca F, Petrucci MT, Pantani L, Galli M, Di Raimondo F, Crippa C, Zamagni E, Palumbo A, Offidani M, Corradini P, Narni F, Spadano A, Pescosta N, Deliliers GL, Ledda A, Cellini C, Caravita T, Tosi P, Baccarani M, GIMEMA Italian Myeloma Network (2010) Bortezomib with thalidomide plus dexamethasone compared with thalidomide plus dexamethasone as induction therapy before, and consolidation therapy after, double autologous stem-cell transplantation in newly diagnosed multiple myeloma: a randomised phase 3 study. Lancet 376(9758): 2075-2085. https://doi.org/10.1016/S0140-6736(10)61424-9

28. Harousseau JL, Attal M, Avet-Loiseau H, Marit G, Caillot D, Mohty M, Lenain P, Hulin C, Facon T, Casassus P, Michallet M, Maisonneuve H, Benboubker L, Maloisel F, Petillon MO, Webb I, Mathiot C, Moreau P (2010) Bortezomib plus dexamethasone is superior to vincristine plus doxorubicin plus dexamethasone as induction treatment prior to autologous stem-cell transplantation in newly diagnosed multiple myeloma: results of the IFM 2005-01 phase III trial. J Clin Oncol 28(30):4621-4629. https://doi.org/10. 1200/JCO.2009.27.9158

29. Lokhorst HM, van der Holt B, Zweegman S, Vellenga E, Croockewit S, van Oers MH, von dem Borne P, Wijermans P, Schaafsma R, de Weerdt O, Wittebol S, Delforge M, Berenschot H, Bos GM, Jie KS, Sinnige H, van Marwijk-Kooy M, Joosten P, Minnema MC, van Ammerlaan R, Sonneveld P, Dutch-Belgian Hemato-Oncology Group (2010) A randomized phase 3 study on the effect of thalidomide combined with adriamycin, dexamethasone, and high-dose melphalan, followed by thalidomide 
maintenance in patients with multiple myeloma. Blood 115(6): 1113-1120. https://doi.org/10.1182/blood-2009-05-222539

30. Moreau P, Avet-Loiseau H, Facon T, Attal M, Tiab M, Hulin C, Doyen C, Garderet L, Randriamalala E, Araujo C, Lepeu G, Marit G, Caillot D, Escoffre M, Lioure B, Benboubker L, Pegourie B, Kolb B, Stoppa AM, Fuzibet JG, Decaux O, Dib M, Berthou C, Chaleteix C, Sebban C, Traulle C, Fontan J, Wetterwald M, Lenain P, Mathiot C, Harousseau JL (2011) Bortezomib plus dexamethasone versus reduced-dose bortezomib, thalidomide plus dexamethasone as induction treatment before autologous stem cell transplantation in newly diagnosed multiple myeloma. Blood 118(22):5752-5758. https://doi.org/10.1182/blood-2011-05355081

31. Rosinol L, Oriol A, Teruel AI, Hernandez D, Lopez-Jimenez J, de la Rubia J, Granell M, Besalduch J, Palomera L, Gonzalez Y, Etxebeste MA, Diaz-Mediavilla J, Hernandez MT, de Arriba F, Gutierrez NC, Martin-Ramos ML, Cibeira MT, Mateos MV, Martinez J, Alegre A, Lahuerta JJ, San Miguel J, Blade J, Programa para el Estudio y la Terapeutica de las Hemopatias Malignas/Grupo Espanol de Mieloma g (2012) Superiority of bortezomib, thalidomide, and dexamethasone (VTD) as induction pretransplantation therapy in multiple myeloma: a randomized phase 3 PETHEMA/GEM study. Blood 120(8):1589-1596. https://doi.org/10.1182/blood-2012-02-408922

32. Sonneveld P, Schmidt-Wolf IG, van der Holt B, El Jarari L, Bertsch U, Salwender H, Zweegman S, Vellenga E, Broyl A, Blau IW, Weisel KC, Wittebol S, Bos GM, Stevens-Kroef M, Scheid C, Pfreundschuh M, Hose D, Jauch A, van der Velde H, Raymakers R, Schaafsma MR, Kersten MJ, van Marwijk-Kooy M, Duehrsen U, Lindemann W, Wijermans PW, Lokhorst HM, Goldschmidt HM (2012) Bortezomib induction and maintenance treatment in patients with newly diagnosed multiple myeloma: results of the randomized phase III HOVON-65/ GMMG-HD4 trial. J Clin Oncol 30(24):2946-2955. https://doi.org/10.1200/ JCO.2011.39.6820

33. Mai EK, Bertsch U, Durig J, Kunz C, Haenel M, Blau IW, Munder M, Jauch A, Schurich B, Hielscher T, Merz M, Huegle-Doerr B, Seckinger A, Hose D, Hillengass J, Raab MS, Neben K, Lindemann HW, Zeis M, Gerecke C, Schmidt-Wolf IG, Weisel K, Scheid C, Salwender H, Goldschmidt H (2015) Phase III trial of bortezomib, cyclophosphamide and dexamethasone (VCD) versus bortezomib, doxorubicin and dexamethasone (PAd) in newly diagnosed myeloma. Leukemia 29(8):1721-1729. https://doi.org/10.1038/leu.2015. 80

34. Moreau P, Hulin C, Macro M, Caillot D, Chaleteix C, Roussel M, Garderet L, Royer B, Brechignac S, Tiab M, Puyade M, Escoffre M, Stoppa AM, Facon T, Pegourie B, Chaoui D, Jaccard A, Slama B, Marit G, Laribi K, Godmer P, Luycx O, Eisenmann JC, Allangba O, Dib M, Araujo C, Fontan J, Belhadj K, Wetterwald M, Dorvaux V, Fermand JP, Rodon P, Kolb B, Glaisner S, Malfuson JV, Lenain P, Biron L, Planche L, Caillon H, AvetLoiseau H, Dejoie T, Attal M (2016) VTD is superior to VCD prior to intensive therapy in multiple myeloma: results of the prospective IFM2013-04 trial. Blood 127(21):2569-2574. https://doi. org/10.1182/blood-2016-01-693580

35. Niesvizky R, Flinn IW, Rifkin R, Gabrail N, Charu V, Clowney B, Essell J, Gaffar Y, Warr T, Neuwirth R, Zhu Y, Elliott J, Esseltine DL, Niculescu L, Reeves J (2015) Community-based phase IIIB trial of three UPFRONT bortezomib-based myeloma regimens. J Clin Oncol 33(33):3921-3929. https://doi.org/10.1200/JCO.2014. 58.7618

36. Mateos M-V, San Miguel JF (2012) Safety and efficacy of subcutaneous formulation of bortezomib versus the conventional intravenous formulation in multiple myeloma. Ther Adv Hematol 3(2): 117-124. https://doi.org/10.1177/2040620711432020
37. Jakubowiak AJ, Dytfeld D, Griffith KA, Lebovic D, Vesole DH, Jagannath S, Al-Zoubi A, Anderson T, Nordgren B, DetweilerShort K, Stockerl-Goldstein K, Ahmed A, Jobkar T, Durecki DE, McDonnell K, Mietzel M, Couriel D, Kaminski M, Vij R (2012) A phase $1 / 2$ study of carfilzomib in combination with lenalidomide and low-dose dexamethasone as a frontline treatment for multiple myeloma. Blood 120(9):1801-1809. https://doi.org/10.1182/ blood-2012-04-422683

38. Korde N, Roschewski M, Zingone A, Kwok M, Manasanch EE, Bhutani M, Tageja N, Kazandjian D, Mailankody S, Wu P, Morrison C, Costello R, Zhang Y, Burton D, Mulquin M, Zuchlinski D, Lamping L, Carpenter A, Wall Y, Carter G, Cunningham SC, Gounden V, Sissung TM, Peer C, Maric I, Calvo KR, Braylan R, Yuan C, Stetler-Stevenson M, Arthur DC, Kong KA, Weng L, Faham M, Lindenberg L, Kurdziel K, Choyke P, Steinberg SM, Figg W, Landgren O (2015) Treatment with carfilzomib-lenalidomide-dexamethasone with lenalidomide extension in patients with smoldering or newly diagnosed multiple myeloma. JAMA Oncol 1(6):746-754. https://doi.org/10.1001/ jamaoncol.2015.2010

39. Roussel M, Lauwers-Cances V, Robillard N, Belhadj K, Facon T, Garderet L, Escoffre M, Pegourie B, Benboubker L, Caillot D, Fohrer C, Moreau P, Leleu X, Avet-Loiseau H, Attal M (2016) Frontline therapy with carfilzomib, lenalidomide, and dexamethasone (KRd) induction followed by autologous stem cell transplantation, KRd consolidation and lenalidomide maintenance in newly diagnosed multiple myeloma (NDMM) patients: primary results of the Intergroupe Francophone Du MyéLome (IFM) KRd phase II study. ASH Annual Meeting Abstracts A1142

40. Moreau P, Hulin C, Caillot D, Marit G, Perrot A, Garderet L, Facon T, Benboubker L, Karlin L, Tiab M, Arnulf B, Fermand JP, Leleu X, Touzeau C, Roussel M, Planche L, Minivielle S, Bene M, Avet-Loiseau H, Dejoie T, Attal M (2016) Ixazomiblenalidomide-dexamethasone (IRd) combination before and after autologous stem cell transplantation (ASCT) followed by ixazomib maintenance in patients with newly diagnosed multiple myeloma (NDMM): a phase 2 study from the Intergroupe Francophone Du MyéLome (IFM). ASH Annual Meeting Abstracts A674

41. ECOG-ACRIN Cancer Research Group (2016) Bortezomib or carfilzomib with lenalidomide and dexamethasone in treating patients with newly diagnosed multiple myeloma. https:// clinicaltrials.gov/ct $2 / \mathrm{show} / \mathrm{NCT} 01863550$ ?term= NCT01863550\&rank=1. Accessed June 2016

42. University of Leeds (2016) Use of thalidomide, lenalidomide, carfilzomib, bortezomib and vorinostat in the initial treatment of newly diagnosed multiple myeloma patients (Myeloma XI). https://clinicaltrials.gov/ct2/show/NCT01554852. Accessed August 2016

43. Pawlyn C, Davies FE, Cairns DA, Collett C, Chalmers A, Striha A, Jones JR, Garg M, Allotey D, Karunanithi K, Milligan D, Kaiser MF, Jenner MW, Cook G, Russell NH, Drayson MT, Owen RG, Gregory WM, Jackson GH, Morgan GJ (2015) Quadruplet vs sequential triplet induction therapy approaches to maximise response for newly diagnosed, transplant eligible, myeloma patients. Blood 126:189

44. Pawlyn C, Davies F, Cairns DA, Striha A, Waterhouse A, Collett C, Jones J, Kishore B, Garg M, Williams C, Karunanithi K, Lindsay J, Jenner M, Cook G, Kaiser M, Drayson M, Owen RG, Russell N, Gregory W, Morgan G, Jackson GH (2017) Quadruplet vs sequential triplet induction therapy for myeloma patients results of the myeloma XI study. Abstract S407. Haematologica 102(s2): $1-882$

45. Center UoHM (2016) A phase III trial on the effect of elotuzumab in VRD induction/consolidation and lenalidomide maintenance in patients with newly diagnosed myeloma (GMMG-HD6). https:// 
clinicaltrials.gov/ct2/show/NCT02495922?term= NCT02495922\&rank=1. Accessed June 2016

46. Landgren O, Iskander K (2017) Modern multiple myeloma therapy: deep, sustained treatment response and good clinical outcomes. J Intern Med 281(4):365-382. https://doi.org/10.1111/ joim. 12590

47. Rajkumar SV (2016) Myeloma today: disease definitions and treatment advances. Am J Hematol 91(1):90-100. https://doi. org/10.1002/ajh.24236

48. Sonneveld P, Beksac M, Van der Holt B, Dimopoulos M, Carella AM, Ludwig H, Driessen C, Wester R, Hajek R, Croockewit S, Troia R, Gay F, Cafro AM, De Rosa L, Fioritoni G, Mellqvist UH, Johnsen HE, Zweegman S, Wu KL, Parreira J, Schjesvold FH, D'Rozario J, Palumbo A, Cavo M (2016) Consolidation followed by maintenance therapy versus maintenance alone in newly diagnosed, transplant eligible patients with multiple myeloma (MM): a randomized phase 3 study of the European Myeloma Network (EMN02/HO95 MM trial). ASH Annual Meeting Abstracts A242

49. Stadtmauer E, Pasquini MC, Blackwell B, Knust K, Bashy A, Devine SM, Efebera YA, Ganguly S, Gasparetto C, Geller N, Giralt S, Hari P, Horowitz MM, Koreth J, Landau H, McCarthy P, McClune B, Nelson C, Qazilbash MH, Shah N, Vesole DH, Vij R, Vogl DT, Somlo G, Krishnan A (2016) Comparison of autologous hematopoietic cell transplant (autoHCT), bortezomib, lenalidomide (Len) and dexamethasone (RVD) consolidation with Len maintenance (ACM), tandem autoHCT with Len maintenance (TAM) and autoHCT with Len maintenance (AM) for up-front treatment of patients with multiple myeloma (MM): primary results from the randomized phase III trial of the Blood and Marrow Transplant Clinical Trials Network (BMT CTN 0702-StaMINA trial). ASH Annual Meeting Abstracts LBA-1

50. Attal M, Harousseau JL, Leyvraz S, Doyen C, Hulin C, Benboubker L, Yakoub Agha I, Bourhis JH, Garderet L, Pegourie B, Dumontet C, Renaud M, Voillat L, Berthou C, Marit G, Monconduit M, Caillot D, Grobois B, Avet-Loiseau H, Moreau P, Facon T, Inter-Groupe Francophone du Myelome (2006) Maintenance therapy with thalidomide improves survival in patients with multiple myeloma. Blood 108(10):3289-3294. https://doi.org/10.1182/blood-2006-05-022962

51. Attal M, Palumbo A, Holstein SA, Lauwers-Cances V, Petrucci MT, Richardson PG, Hulin C, Tosi P, Anderson KC, Caillot D, Magarotto V, Moreau P, Marit G, Yu Z, McCarthy PL (2016) Lenalidomide (LEN) maintenance (MNTC) after high-dose melphalan and autologous stem cell transplant (ASCT) in multiple myeloma (MM): a meta-analysis (MA) of overall survival (OS). J Clin Oncol 34(suppl; abstr 8001)

52. Sengsayadeth S, Malard F, Savani BN, Garderet L, Mohty M (2017) Posttransplant maintenance therapy in multiple myeloma: the changing landscape. Blood Cancer J 7(3):e545. https://doi.org/ 10.1038 /bcj.2017.23

53. Jackson GH, Davies F, Pawlyn C, Cairns DA, Striha A, Waterhouse A, Jones J, Kishore B, Garg M, Williams C, Karunanithi K, Lindsay J, Jenner M, Cook G, Kaiser M, Drayson M, Owen RG, Russell N, Gregory W, Morgan GJ, NCRI Haemato-Oncology Clinical Studies Group (2017) Lenalidomide induction and maintenance therapy for transplant eligible myeloma patients: results of the Myeloma XI study. J Clin Oncol 35(15 suppl):8009. https://doi.org/10.1200/JCO.2017.35. 15_suppl.8009

54. Celgene Ltd (2017) Revlimid (lenalidomide) summary of product characteristics. http://www.ema.europa.eu/docs/en_GB/ document_library/EPAR__Product_Information/human/000717/ WC500056018.pdf. Accessed March 2018

55. Pulte ED, Dmytrijuk A, Nie L, Goldberg KB, McKee AE, Farrell AT, Pazdur R (2018) FDA approval summary: lenalidomide as maintenance therapy after autologous stem cell transplant in newly diagnosed multiple myeloma. Oncologist 23(6):734-739 https:// doi.org/10.1634/theoncologist.2017-0440

56. Goldschmidt H, Lokhorst HM, Mai EK, van der Holt B, Blau IW, Zweegman S, Weisel KC, Vellenga E, Pfreundschuh M, Kersten MJ, Scheid C, Croockewit S, Raymakers R, Hose D, Potamianou A, Jauch A, Hillengass J, Stevens-Kroef M, Raab MS, Broijl A, Lindemann HW, Bos GMJ, Brossart P, van Marwijk KM, Ypma P, Duehrsen U, Schaafsma RM, Bertsch U, Hielscher T, Jarari L, Salwender HJ, Sonneveld P (2018) Bortezomib before and after high-dose therapy in myeloma: long-term results from the phase III HOVON-65/GMMG-HD4 trial. Leukemia 32(2):383-390. https://doi.org/10.1038/leu.2017.211

57. Larocca A, Palumbo A (2015) How I treat fragile myeloma patients. Blood 126(19):2179-2185. https://doi.org/10.1182/blood2015-05-612960

58. Palumbo A, Bringhen S, Liberati AM, Caravita T, Falcone A, Callea V, Montanaro M, Ria R, Capaldi A, Zambello R, Benevolo G, Derudas D, Dore F, Cavallo F, Gay F, Falco P, Ciccone G, Musto P, Cavo M, Boccadoro M (2008) Oral melphalan, prednisone, and thalidomide in elderly patients with multiple myeloma: updated results of a randomized controlled trial. Blood 112(8):3107-3114. https://doi.org/10.1182/blood-2008-04149427

59. Mateos MV, Oriol A, Martinez-Lopez J, Gutierrez N, Teruel AI, de Paz R, Garcia-Larana J, Bengoechea E, Martin A, Mediavilla JD, Palomera L, de Arriba F, Gonzalez Y, Hernandez JM, Sureda A, Bello JL, Bargay J, Penalver FJ, Ribera JM, Martin-Mateos ML, Garcia-Sanz R, Cibeira MT, Ramos ML, Vidriales MB, Paiva B, Montalban MA, Lahuerta JJ, Blade J, Miguel JF (2010) Bortezomib, melphalan, and prednisone versus bortezomib, thalidomide, and prednisone as induction therapy followed by maintenance treatment with bortezomib and thalidomide versus bortezomib and prednisone in elderly patients with untreated multiple myeloma: a randomised trial. Lancet Oncol 11(10):934-941. https://doi.org/10.1016/S1470-2045(10)70187-X

60. Stewart AK, Jacobus S, Fonseca R, Weiss M, Callander NS, Chanan-Khan AA, Rajkumar SV (2015) Melphalan, prednisone, and thalidomide vs melphalan, prednisone, and lenalidomide (ECOG E1A06) in untreated multiple myeloma. Blood 126(11): 1294-1301. https://doi.org/10.1182/blood-2014-12-613927

61. Hungria VT, Crusoe EQ, Maiolino A, Bittencourt R, Fantl D, Maciel JF, Pessoa de Magalhaes RJ, Almeida MS, Cury P, Hisgashi F, Peres AL, Chiattone CS (2016) Phase 3 trial of three thalidomide-containing regimens in patients with newly diagnosed multiple myeloma not transplant-eligible. Ann Hematol 95(2):271-278. https://doi.org/10.1007/s00277-015-2537-2

62. Magarotto V, Bringhen S, Offidani M, Benevolo G, Patriarca F, Mina R, Falcone AP, De Paoli L, Pietrantuono G, Gentili S, Musolino C, Giuliani N, Bernardini A, Conticello C, Pulini S, Ciccone G, Maisnar V, Ruggeri M, Zambello R, Guglielmelli T, Ledda A, Liberati AM, Montefusco V, Hajek R, Boccadoro M, Palumbo A (2016) Triplet vs doublet lenalidomide-containing regimens for the treatment of elderly patients with newly diagnosed multiple myeloma. Blood 127(9):1102-1108. https://doi.org/10. 1182/blood-2015-08-662627

63. Hulin C, Belch A, Shustik C, Petrucci MT, Duhrsen U, Lu J, Song K, Rodon P, Pegourie B, Garderet L, Hunter H, Azais I, Eek R, Gisslinger H, Macro M, Dakhil S, Goncalves C, LeBlanc R, Romeril K, Royer B, Doyen C, Leleu X, Offner F, Leupin N, Houck V, Chen G, Ervin-Haynes A, Dimopoulos MA, Facon T (2016) Updated outcomes and impact of age with lenalidomide and low-dose dexamethasone or melphalan, prednisone, and thalidomide in the randomized, phase III FIRST trial. J Clin Oncol 34(30):3609-3617 https://doi.org/10.1200/JCO.2016.66.7295

64. Durie BG, Hoering A, Abidi MH, Rajkumar SV, Epstein J, Kahanic SP, Thakuri M, Reu F, Reynolds CM, Sexton R, 
Orlowski RZ, Barlogie B, Dispenzieri A (2017) Bortezomib with lenalidomide and dexamethasone versus lenalidomide and dexamethasone alone in patients with newly diagnosed myeloma without intent for immediate autologous stem-cell transplant (SWOG S0777): a randomised, open-label, phase 3 trial. Lancet 389(10068):519-527. https://doi.org/10.1016/S0140-6736(16) 31594-X

65. Mateos MV, Dimopoulos MA, Cavo M, Suzuki K, Jakubowiak A, Knop S, Doyen C, Lucio P, Nagy Z, Kaplan P, Pour L, Cook M, Grosicki S, Crepaldi A, Liberati AM, Campbell P, Shelekhova T, Yoon SS, Iosava G, Fujisaki T, Garg M, Chiu C, Wang J, Carson R, Crist W, Deraedt W, Nguyen H, Qi M, San-Miguel J (2018) Daratumumab plus bortezomib, melphalan, and prednisone for untreated myeloma. N Engl J Med 378(6):518-528. https://doi. org/10.1056/NEJMoa1714678

66. Mateos MV, Martinez-Lopez J, Hernandez MT, Ocio EM, Rosinol L, Martinez R, Teruel AI, Gutierrez NC, Martin Ramos ML, Oriol A, Bargay J, Bengoechea E, Gonzalez Y, Perez de Oteyza J, Gironella M, Encinas C, Martin J, Cabrera C, Paiva B, Cedena MT, Puig N, Blade J, Lahuerta JJ, San-Miguel J (2016) Sequential vs alternating administration of VMP and Rd in elderly patients with newly diagnosed MM. Blood 127(4):420-425. https://doi. org/10.1182/blood-2015-08-666537

67. Palumbo A, Bringhen S, Mateos MV, Larocca A, Facon T, Kumar SK, Offidani M, McCarthy P, Evangelista A, Lonial S, Zweegman S, Musto P, Terpos E, Belch A, Hajek R, Ludwig H, Stewart AK, Moreau P, Anderson K, Einsele H, Durie BG, Dimopoulos MA, Landgren O, San Miguel JF, Richardson P, Sonneveld P, Rajkumar SV (2015) Geriatric assessment predicts survival and toxicities in elderly myeloma patients: an International Myeloma Working Group report. Blood 125(13):2068-2074. https://doi.org/ 10.1182/blood-2014-12-615187

68. Engelhardt M, Dold SM, Ihorst G, Zober A, Moller M, Reinhardt H, Hieke S, Schumacher M, Wasch R (2016) Geriatric assessment in multiple myeloma patients: validation of the International Myeloma Working Group (IMWG) score and comparison with other common comorbidity scores. Haematologica 101(9):1110 1119. https://doi.org/10.3324/haematol.2016.148189

69. Bonomo L, Lue J, Jagannath S, Chari A (2016) The outcomes of newly diagnosed elderly multiple myeloma patients treated at a single U.S. institution. Cancer Med 5(3):500-505. https://doi.org/ 10.1002/cam4.620

70. Mateos MV, Oriol A, Martinez-Lopez J, Teruel AI, Lopez de la Guia A, Lopez J, Bengoechea E, Perez M, Martinez R, Palomera L, de Arriba F, Gonzalez Y, Hernandez JM, Granell M, Bello JL, Bargay J, Penalver FJ, Martin-Mateos ML, Paiva B, Montalban MA, Blade J, Lahuerta JJ, San-Miguel JF (2014) GEM2005 trial update comparing VMP/VTP as induction in elderly multiple myeloma patients: do we still need alkylators? Blood 124(12):18871893. https://doi.org/10.1182/blood-2014-05-573733

71. Morgan GJ, Schey SA, Wu P, Srikanth M, Phekoo KJ, Jenner M, Davies FE (2007) Lenalidomide (Revlimid), in combination with cyclophosphamide and dexamethasone (RCD), is an effective and tolerated regimen for myeloma patients. Br J Haematol 137(3): 268-269. https://doi.org/10.1111/j.1365-2141.2007.06538.x

72. Sonneveld P, Broijl A (2016) Treatment of relapsed and refractory multiple myeloma. Haematologica 101(4):396-406. https://doi. org/10.3324/haematol.2015.129189

73. Laubach J, Garderet L, Mahindra A, Gahrton G, Caers J, Sezer O, Voorhees P, Leleu X, Johnsen HE, Streetly M, Jurczyszyn A, Ludwig H, Mellqvist UH, Chng WJ, Pilarski L, Einsele H, Hou J, Turesson I, Zamagni E, Chim CS, Mazumder A, Westin J, Lu J, Reiman T, Kristinsson S, Joshua D, Roussel M, O'Gorman P, Terpos E, McCarthy P, Dimopoulos M, Moreau P, Orlowski RZ, Miguel JS, Anderson KC, Palumbo A, Kumar S, Rajkumar V, Durie B, Richardson PG (2016) Management of relapsed multiple myeloma: recommendations of the International Myeloma Working Group. Leukemia 30(5):1005-1017. https://doi.org/10.1038/leu.2015.356

74. Cook G, Ashcroft AJ, Cairns DA, Williams CD, Brown JM, Cavenagh JD, Snowden JA, Parrish C, Yong K, Cavet J, Hunter H, Bird JM, Pratt G, Chown S, Heartin E, O'Connor S, Drayson MT, Hockaday A, Morris TC, National Cancer Research Institute Haemato-oncology Clinical Studies Group (2016) The effect of salvage autologous stem-cell transplantation on overall survival in patients with relapsed multiple myeloma (final results from BSBMT/UKMF myeloma $\mathrm{X}$ relapse [intensive]): a randomised, open-label, phase 3 trial. Lancet Haematol 3(7):e340-e351. https://doi.org/10.1016/S2352-3026(16)30049-7

75. Cook G, Williams C, Brown JM, Cairns DA, Cavenagh J, Snowden JA, Ashcroft AJ, Fletcher M, Parrish C, Yong K, Cavet J, Hunter H, Bird JM, Chalmers A, O'Connor S, Drayson MT, Morris TC, National Cancer Research Institute Haematooncology Clinical Studies Group (2014) High-dose chemotherapy plus autologous stem-cell transplantation as consolidation therapy in patients with relapsed multiple myeloma after previous autologous stem-cell transplantation (NCRI myeloma X relapse [intensive trial]): a randomised, open-label, phase 3 trial. Lancet Oncol 15(8):874-885. https://doi.org/10.1016/S1470-2045(14)70245-1

76. Singh Abbi KK, Zheng J, Devlin SM, Giralt S, Landau H (2015) Second autologous stem cell transplant: an effective therapy for relapsed multiple myeloma. Biol Blood Marrow Transplant 21(3): 468-472. https://doi.org/10.1016/j.bbmt.2014.11.677

77. Garderet L, Iacobelli S, van Biezen A, Koster L, Dreger P, Johanssen J-E, Leleu X, Potter M, Krejcj M, Peschel C, Radocha J, Ganser A, Metzner B, Paoli N, Schäfer-Eckart K, Pohlreich D, Lenain P, Grasso M, Caillot D, Einsele H, Sengeloev H, Meuleman N, Ciceri F, Schönland S, Kröger N (2016) Outcome of third salvage autologous stem cell transplantation in multiple myeloma. ASH Annual Meeting Abstracts A993

78. Mikhael JR (2014) A practical approach to relapsed multiple myeloma. Hematology Am Soc Hematol Educ Program 2014(1): 262-267. https://doi.org/10.1182/asheducation-2014.1.262

79. Garderet L, Iacobelli S, Moreau P, Dib M, Lafon I, Niederwieser D, Masszi T, Fontan J, Michallet M, Gratwohl A, Milone G, Doyen C, Pegourie B, Hajek R, Casassus P, Kolb B, Chaleteix C, Hertenstein B, Onida F, Ludwig H, Ketterer N, Koenecke C, van Os M, Mohty M, Cakana A, Gorin NC, de Witte T, Harousseau JL, Morris C, Gahrton G (2012) Superiority of the triple combination of bortezomib-thalidomide-dexamethasone over the dual combination of thalidomide-dexamethasone in patients with multiple myeloma progressing or relapsing after autologous transplantation: the MMVAR/IFM 2005-04 randomized phase III trial from the Chronic Leukemia Working Party of the European Group for Blood and Marrow Transplantation. J Clin Oncol 30(20):2475-2482. https://doi.org/10.1200/JCO.2011.37. 4918

80. Baz R, Martin TG, Alsina M, Shain KH, Cho HJ, Wolf JL, Mahindra A, Chari A, Sullivan DM, Nardelli LA, Lau K, Zhao X, Lin H-Y, Jagannath S (2014) Pomalidomide, cyclophosphamide, and dexamethasone is superior to pomalidomide and dexamethasone in relapsed and refractory myeloma: results of a multicenter randomized phase II study. Blood 124:303

81. Glasmacher A, Hahn C, Hoffmann F, Naumann R, Goldschmidt $\mathrm{H}$, von Lilienfeld-Toal M, Orlopp K, Schmidt-Wolf I, Gorschluter M (2006) A systematic review of phase-II trials of thalidomide monotherapy in patients with relapsed or refractory multiple myeloma. Br J Haematol 132(5):584-593. https://doi.org/10.1111/j. 1365-2141.2005.05914.x

82. Dimopoulos M, Spencer A, Attal M, Prince HM, Harousseau JL, Dmoszynska A, San Miguel J, Hellmann A, Facon T, Foa R, Corso A, Masliak Z, Olesnyckyj M, Yu Z, Patin J, Zeldis JB, 
Knight RD, Multiple Myeloma Study Investigators (2007) Lenalidomide plus dexamethasone for relapsed or refractory multiple myeloma. N Engl J Med 357(21):2123-2132. https://doi.org/ 10.1056/NEJMoa070594

83. Weber DM, Chen C, Niesvizky R, Wang M, Belch A, Stadtmauer EA, Siegel D, Borrello I, Rajkumar SV, Chanan-Khan AA, Lonial S, Yu Z, Patin J, Olesnyckyj M, Zeldis JB, Knight RD, Multiple Myeloma Study Investigators (2007) Lenalidomide plus dexamethasone for relapsed multiple myeloma in North America. $\mathrm{N}$ Engl J Med 357(21):2133-2142. https://doi.org/10.1056/ NEJMoa070596

84. Amgen Ltd (2017) Second phase 3 study shows KYPROLIS $®$ (carfilzomib) regimen significantly improves overall survival in patients with relapsed multiple myeloma. https://www.amgen. com/media/news-releases/2017/07/second-phase-3-study-showskyprolis-carfilzomib-regimen-significantly-improves-overallsurvival-in-patients-with-relapsed-multiple-myeloma/. Accessed 4 October 2017

85. Takeda Pharma A/S (2016) Ninlaro (ixazomib) summary of product characteristics. http://www.ema.europa.eu/docs/en_GB/ document_library/EPAR_-_Product_Information/human/003844/ WC500217620.pdf. Accessed December 2016

86. Celgene Ltd (2015) Imnovid (pomalidomide) summary of product characteristics. http://www.ema.europa.eu/docs/en_GB/ document_library/EPAR__Product_Information/human/002682/ WC500147717.pdf. Accessed June 2016

87. Lacy MQ, LaPlant BR, Laumann KM, Kumar S, Gertz MA, Hayman SR, Buadi F, Dispenzieri A, Lust JA, Kapoor P, Leung N, Russell SJ, Dingli D, Gonsalves WI, Fonseca R, Bergsagel PL, Roy V, Sher T, Ailawadhi S, Chanan-Khan A, Stewart AK, Reeder CB, Rajkumar SV, Mikhael JR (2014) Pomalidomide, bortezomib and dexamethasone (PVD) for patients with relapsed lenalidomide refractory multiple myeloma (MM). Blood 124:304

88. Bringhen S, Magarotto V, Liberati AM, Belotti A, Larocca A, Gilestro M, Bonello F, Gaidano G, Bertazzoni P, Stocchi R, Ribolla R, Di Sano C, Patriarca F, Passera R, De Paoli L, Oliva S, Cafro AM, Sonneveld P, Palumbo A, Boccadoro M (2016) A multicenter, open label phase I/II study of carfilzomib, pomalidomide and dexamethasone in relapsed and/or refractory multiple myeloma (MM) patients. ASH Annual Meeting Abstracts A1145

89. Plesner T, Arkenau HT, Gimsing P, Krejcik J, Lemech C, Minnema MC, Lassen U, Laubach JP, Palumbo A, Lisby S, Basse L, Wang J, Sasser AK, Guckert ME, de Boer C, Khokhar NZ, Yeh H, Clemens PL, Ahmadi T, Lokhorst HM, Richardson PG (2016) Phase 1/2 study of daratumumab, lenalidomide, and dexamethasone for relapsed multiple myeloma. Blood 128:18211828. https://doi.org/10.1182/blood-2016-07-726729

90. Lokhorst HM, Plesner T, Laubach JP, Nahi H, Gimsing P, Hansson M, Minnema MC, Lassen U, Krejcik J, Palumbo A, van de Donk NW, Ahmadi T, Khan I, Uhlar CM, Wang J, Sasser AK, Losic N, Lisby S, Basse L, Brun N, Richardson PG (2015) Targeting CD38 with daratumumab monotherapy in multiple myeloma. N Engl J Med 373(13):1207-1219. https://doi.org/ 10.1056/NEJMoa1506348

91. Jakubowiak A, Offidani M, Pegourie B, De La Rubia J, Garderet L, Laribi K, Bosi A, Marasca R, Laubach J, Mohrbacher A, Carella AM, Singhal AK, Tsao LC, Lynch M, Bleickardt E, Jou YM, Robbins M, Palumbo A (2016) Randomized phase 2 study: elotuzumab plus bortezomib/dexamethasone vs bortezomib/ dexamethasone for relapsed/refractory MM. Blood 127(23): 2833-2840. https://doi.org/10.1182/blood-2016-01-694604

92. Janssen Research \& Development LLC (2016) Addition of daratumumab to combination of bortezomib and dexamethasone in participants with relapsed or refractory multiple myeloma.
https://clinicaltrials.gov/ct2/show/NCT02136134?term= NCT02136134\&rank=1. Accessed June 2016

93. Bristol-Myers Squibb (2016) Phase III study of lenalidomide and dexamethasone with or without elotuzumab to treat relapsed or refractory multiple myeloma (ELOQUENT-2). https:// clinicaltrials.gov/ct $2 /$ show $/$ NCT0 1239797 ?term= NCT01239797\&rank=1. Accessed June 2016

94. Janssen Research \& Development LLC (2016) A study comparing daratumumab, lenalidomide, and dexamethasone with lenalidomide and dexamethasone in relapsed or refractory multiple myeloma. https:/clinicaltrials.gov/ct2/show/NCT02076009? term $=$ NCT02076009\&rank=1. Accessed June 2016

95. Lonial S, Durie B, Palumbo A, San-Miguel J (2016) Monoclonal antibodies in the treatment of multiple myeloma: current status and future perspectives. Leukemia 30(3):526-535. https://doi. org/10.1038/leu.2015.223

96. Amgen Ltd (2015) Kyprolis (carfilzomib) summary of product characteristics. http://www.ema.europa.eu/docs/en GB/ document_library/EPAR___Product_Information/human/003790/ WC500197692pdf Accessed June 2016

97. Janssen-Cillag NV (2016) Velcade (bortezomib) summary of product characteristics. http://www.ema.europa.eu/docs/en_GB/ document library/EPAR _ Product Information/human/000539/ WC500048471.pdf. Accessed June 2016

98. Lacy MQ, Hayman SR, Gertz MA, Short KD, Dispenzieri A, Kumar S, Greipp PR, Lust JA, Russell SJ, Dingli D, Zeldenrust S, Fonseca R, Bergsagel PL, Roy V, Mikhael JR, Stewart AK, Laumann K, Allred JB, Mandrekar SJ, Rajkumar SV, Buadi F (2010) Pomalidomide (CC4047) plus low dose dexamethasone (Pom/dex) is active and well tolerated in lenalidomide refractory multiple myeloma (MM). Leukemia 24(11):1934-1939. https:// doi.org/10.1038/leu.2010.190

99. Dimopoulos MA, Palumbo A, Corradini P, Cavo M, Delforge M, Di Raimondo F, Weisel KC, Oriol A, Hansson M, Vacca A, Blanchard MJ, Goldschmidt H, Doyen C, Kaiser M, Petrini M, Anttila P, Cafro AM, Raymakers R, San-Miguel J, de Arriba F, Knop S, Rollig C, Ocio EM, Morgan G, Miller N, Simcock M, Peluso T, Herring J, Sternas L, Zaki MH, Moreau P (2016) Safety and efficacy of pomalidomide plus low-dose dexamethasone in STRATUS (MM-010): a phase $3 \mathrm{~b}$ study in refractory multiple myeloma. Blood 128(4):497-503. https://doi.org/10.1182/blood2016-02-700872

100. Shah JJ, Stadtmauer EA, Abonour R, Cohen AD, Bensinger WI, Gasparetto C, Kaufman JL, Lentzsch S, Vogl DT, Gomes CL, Pascucci N, Smith DD, Orlowski RZ, Durie BG (2015) Carfilzomib, pomalidomide, and dexamethasone for relapsed or refractory myeloma. Blood 126(20):2284-2290. https://doi.org/ 10.1182/blood-2015-05-643320

101. Chari A, Suvannasankha A, Fay JW, Arnulf B, Kaufman JL, Ifthikharuddin JJ, Weiss BM, Krishnan A, Lentzsch S, Comenzo R, Wang J, Nottage K, Chiu C, Khokhar NZ, Ahmadi T, Lonial S (2017) Daratumumab plus pomalidomide and dexamethasone in relapsed and/or refractory multiple myeloma. Blood 130(8):974981. https://doi.org/10.1182/blood-2017-05-785246

102. Palumbo A, Avet-Loiseau H, Oliva S, Lokhorst HM, Goldschmidt H, Rosinol L, Richardson P, Caltagirone S, Lahuerta JJ, Facon T, Bringhen S, Gay F, Attal M, Passera R, Spencer A, Offidani M, Kumar S, Musto P, Lonial S, Petrucci MT, Orlowski RZ, Zamagni E, Morgan G, Dimopoulos MA, Durie BG, Anderson KC, Sonneveld P, San Miguel J, Cavo M, Rajkumar SV, Moreau P (2015) Revised international staging system for multiple myeloma: a report from International Myeloma Working Group. J Clin Oncol 33(26):2863-2869. https://doi.org/10.1200/JCO.2015.61. 2267

103. Sonneveld P, Avet-Loiseau H, Lonial S, Usmani S, Siegel D, Anderson KC, Chng WJ, Moreau P, Attal M, Kyle RA, Caers J, 
Hillengass J, San Miguel J, van de Donk NW, Einsele H, Blade J, Durie BG, Goldschmidt H, Mateos MV, Palumbo A, Orlowski R (2016) Treatment of multiple myeloma with high-risk cytogenetics: a consensus of the International Myeloma Working Group. Blood 127(24):2955-2962. https://doi.org/10.1182/blood-201601-631200

104. Dispenzieri A (2016) Myeloma: management of the newly diagnosed high-risk patient. Hematology Am Soc Hematol Educ Program 2016(1):485-494. https://doi.org/10.1182/asheducation2016.1.485

105. Morgan GJ, Davies FE, Gregory WM, Bell SE, Szubert AJ, Navarro Coy N, Cook G, Feyler S, Johnson PR, Rudin C, Drayson MT, Owen RG, Ross FM, Russell NH, Jackson GH, Child JA, National Cancer Research Institute Haematological Oncology Clinical Studies Group (2012) Cyclophosphamide, thalidomide, and dexamethasone as induction therapy for newly diagnosed multiple myeloma patients destined for autologous stemcell transplantation: MRC myeloma IX randomized trial results. Haematologica 97(3):442-450. https://doi.org/10.3324/haematol. 2011.043372

106. Lonial S, Boise LH, Kaufman J (2015) How I treat high-risk myeloma. Blood 126(13):1536-1543. https://doi.org/10.1182/ blood-2015-06-653261

107. Offidani M, Corvatta L, Bringhen S, Gentili S, Troia R, Maracci L, Larocca A, Palumbo A, Leoni P (2016) Impact of cytogenetic risk on PFS2 of patients treated with different therapy sequences: results of a post-hoc analysis

108. Dimopoulos MA, Weisel KC, Song KW, Delforge M, Karlin L, Goldschmidt H, Moreau P, Banos A, Oriol A, Garderet L, Cavo M, Ivanova V, Alegre A, Martinez-Lopez J, Chen C, Spencer A, Knop S, Bahlis NJ, Renner C, Yu X, Hong K, Sternas L, Jacques C, Zaki MH, San Miguel JF (2015) Cytogenetics and long-term survival of patients with refractory or relapsed and refractory multiple myeloma treated with pomalidomide and low-dose dexamethasone. Haematologica 100(10):1327-1333. https://doi.org/ 10.3324/haematol.2014.117077

109. Leleu X, Karlin L, Macro M, Hulin C, Garderet L, Roussel M, Arnulf B, Pegourie B, Kolb B, Stoppa AM, Brechiniac S, Marit G, Thielemans B, Onraed B, Mathiot C, Banos A, Lacotte L, Tiab M, Dib M, Fuzibet JG, Petillon MO, Rodon P, Wetterwald M, Royer B, Legros L, Benboubker L, Decaux O, Escoffre-Barbe M, Caillot D, Fermand JP, Moreau P, Attal M, Avet-Loiseau H, Facon T, Intergroupe Francophone du Myelome (2015) Pomalidomide plus low-dose dexamethasone in multiple myeloma with deletion $17 \mathrm{p}$ and/or translocation $(4 ; 14)$ : IFM 2010-02 trial results. Blood 125(9):1411-1417. https://doi.org/10.1182/blood-2014-11612069

110. Avet-Loiseau H, Fonseca R, Siegel D, Dimopoulos MA, Spicka I, Masszi T, Hajek R, Rosinol L, Goranova-Marinova V, Mihaylov G, Maisnar V, Mateos MV, Wang M, Niesvizky R, Oriol A, Jakubowiak A, Minarik J, Palumbo A, Bensinger W, Kukreti V, Ben-Yehuda D, Stewart AK, Obreja M, Moreau P (2016) Carfilzomib significantly improves the progression-free survival of high-risk patients in multiple myeloma. Blood 128(9):1174 1180. https://doi.org/10.1182/blood-2016-03-707596

111. Mateos M, Estell J, Barreto W, Corradini P, Min C-K, Medvedova E, Qi M, Schecter J, Amin H, Qin X, Deraedt W, Casneuf T, Chiu C, Sasser AK, Nooka AK (2016) Efficacy of daratumumab, bortezomib, and dexamethasone versus bortezomib and dexamethasone in relapsed or refractory myeloma based on prior lines of therapy: updated analysis of CASTOR. Blood 128(22):925969 (Abstract 1150)

112. Usmani S, Dimopoulos M, Belch A, White D, Benboubker L, Cook G, Leiba M, Morton J, Ho PJ, Kim K, Takezako N, Khokhar N, Guckert M, Wu K, Qin X, Casneuf T, Chiu C, Sasser AK, San Miguel J (2016) Efficacy of daratumumab, lenalidomide, and dexamethasone versus lenalidomide and dexamethasone in relapsed or refractory multiple myeloma patients with 1 to 3 prior lines of therapy: updated analysis of POLLUX. Blood 128(22):92-5969 (Abstract 1151)

113. Hájek R, Jarkovsky J, Bouwmeester W, Treur M, DeCosta L, Campioni M, Delforge M, Raab MS, Schoen P, Szabo Z, Lucie B, Gonzalez-McQuire S (2016) Exploration of survival stratification of patients with multiple myeloma after first relapse using real world data. Blood 128(22):2417

114. Decaux O, Lode L, Magrangeas F, Charbonnel C, Gouraud W, Jezequel P, Attal M, Harousseau JL, Moreau P, Bataille R, Campion L, Avet-Loiseau H, Minvielle S (2008) Prediction of survival in multiple myeloma based on gene expression profiles reveals cell cycle and chromosomal instability signatures in highrisk patients and hyperdiploid signatures in low-risk patients: a study of the Intergroupe Francophone du Myelome. J Clin Oncol 26(29):4798-4805. https://doi.org/10.1200/jco.2007.13.8545

115. Kuiper R, Broyl A, de Knegt $Y$, van Vliet MH, van Beers EH, van der Holt B, el Jarari L, Mulligan G, Gregory W, Morgan G, Goldschmidt H, Lokhorst HM, van Duin M, Sonneveld P (2012) A gene expression signature for high-risk multiple myeloma. Leukemia 26(11): 2406-2413. https://doi.org/10.1038/leu.2012.127

116. Shaughnessy JD Jr, Zhan F, Burington BE, Huang Y, Colla S, Hanamura I, Stewart JP, Kordsmeier B, Randolph C, Williams DR, Xiao Y, Xu H, Epstein J, Anaissie E, Krishna SG, CottlerFox M, Hollmig K, Mohiuddin A, Pineda-Roman M, Tricot G, van Rhee F, Sawyer J, Alsayed Y, Walker R, Zangari M, Crowley J, Barlogie B (2007) A validated gene expression model of highrisk multiple myeloma is defined by deregulated expression of genes mapping to chromosome 1. Blood 109(6):2276-2284. https://doi.org/10.1182/blood-2006-07-038430

117. Mulligan G, Lichter DI, Di Bacco A, Blakemore SJ, Berger A, Koenig E, Bernard H, Trepicchio W, Li B, Neuwirth R, Chattopadhyay N, Bolen JB, Dorner AJ, van de Velde H, Ricci D, Jagannath S, Berenson JR, Richardson PG, Stadtmauer EA, Orlowski RZ, Lonial S, Anderson KC, Sonneveld P, San Miguel JF, Esseltine DL, Schu M (2014) Mutation of NRAS but not KRAS significantly reduces myeloma sensitivity to single-agent bortezomib therapy. Blood 123(5):632-639. https://doi.org/10. 1182/blood-2013-05-504340

118. Walker BA, Boyle EM, Wardell CP, Murison A, Begum DB, Dahir NM, Proszek PZ, Johnson DC, Kaiser MF, Melchor L, Aronson LI, Scales M, Pawlyn C, Mirabella F, Jones JR, Brioli A, Mikulasova A, Cairns DA, Gregory WM, Quartilho A, Drayson MT, Russell N, Cook G, Jackson GH, Leleu X, Davies FE, Morgan GJ (2015) Mutational spectrum, copy number changes, and outcome: results of a sequencing study of patients with newly diagnosed myeloma. J Clin Oncol 33(33):3911-3920. https://doi.org/10.1200/jco.2014.59.1503

119. Kumar S, Kaufman JL, Gasparetto C, Mikhael J, Vij R, Pegourie B, Benboubker L, Facon T, Amiot M, Moreau P, Punnoose EA, Alzate S, Dunbar M, Xu T, Agarwal SK, Enschede SH, Leverson JD, Ross JA, Maciag PC, Verdugo M, Touzeau C (2017) Efficacy of venetoclax as targeted therapy for relapsed/refractory $t(11 ; 14)$ multiple myeloma. Blood 130(22):2401-2409. https://doi.org/10. 1182/blood-2017-06-788786

120. Kumar S, Flinn I, Richardson PG, Hari P, Callander N, Noga SJ, Stewart AK, Turturro F, Rifkin R, Wolf J, Estevam J, Mulligan G, Shi H, Webb IJ, Rajkumar SV (2012) Randomized, multicenter, phase 2 study (EVOLUTION) of combinations of bortezomib, dexamethasone, cyclophosphamide, and lenalidomide in previously untreated multiple myeloma. Blood 119(19):4375-4382. https://doi.org/10.1182/blood-2011-11-395749

121. Intergroupe Francophone du Myelome (2016) A study to evaluate daratumumab in transplant eligible participants with previously untreated multiple myeloma (Cassiopeia). https://clinicaltrials. 
gov/ct2/show $/$ NCT02541383?term $=$ NCT02541383\&rank $=1$. Accessed June 2016

122. Bristol-Myers Squibb (2016) Study of combinations of nivolumab, elotuzumab, pomalidomide and dexamethasone in multiple myeloma (CheckMate 602). https://clinicaltrials.gov/ ct $2 /$ show $/$ NCT02726581?term $=$ NCT02726581\&rank $=1$. Accessed June 2016

123. Sonneveld P, De Wit E, Moreau P (2017) How have evolutions in strategies for the treatment of relapsed/refractory multiple myeloma translated into improved outcomes for patients? Crit Rev Oncol Hematol 112:153-170. https://doi.org/10.1016/j. critrevonc.2017.02.007

124. Gaultney JG, Franken MG, Tan SS, Redekop WK, Huijgens PC, Sonneveld P, Uyl-de Groot CA (2013) Real-world health care costs of relapsed/refractory multiple myeloma during the era of novel cancer agents. J Clin Pharm Ther 38(1):41-47. https://doi. org/10.1111/jcpt. 12020 